2020-08

\title{
Predicting the exposure of diving grey seals to shipping noise
}

Trigg, LE

http://hdl.handle.net/10026.1/18270

$10.1121 / 10.0001727$

The Journal of the Acoustical Society of America

Acoustical Society of America (ASA)

All content in PEARL is protected by copyright law. Author manuscripts are made available in accordance with publisher policies. Please cite only the published version using the details provided on the item record or document. In the absence of an open licence (e.g. Creative Commons), permissions for further reuse of content should be sought from the publisher or author. 


\section{Predicting the exposure of diving grey seals to shipping noise}

Leah E. Trigg, Feng Chen, Georgy I. Shapiro, Simon N. Ingram, Cécile Vincent, David Thompson, Debbie J. F. Russell, Matt I. D. Carter, and Clare B. Embling

Citation: The Journal of the Acoustical Society of America 148, 1014 (2020); doi: 10.1121/10.0001727

View online: https://doi.org/10.1121/10.0001727

View Table of Contents: https://asa.scitation.org/toc/jas/148/2

Published by the Acoustical Society of America

\section{ARTICLES YOU MAY BE INTERESTED IN}

The Lombard effect in singing humpback whales: Source levels increase as ambient ocean noise levels increase The Journal of the Acoustical Society of America 148, 542 (2020); https://doi.org/10.1121/10.0001669

Estimating the effects of pile driving sounds on seals: Pitfalls and possibilities

The Journal of the Acoustical Society of America 147, 3948 (2020); https://doi.org/10.1121/10.0001408

Exclusion of tidal influence on ambient sound measurements

The Journal of the Acoustical Society of America 148, 701 (2020); https://doi.org/10.1121/10.0001704

Introduction to the special issue on the effects of sound on aquatic life

The Journal of the Acoustical Society of America 148, 934 (2020); https://doi.org/10.1121/10.0001725

Application of kurtosis to underwater sound

The Journal of the Acoustical Society of America 148, 780 (2020); https://doi.org/10.1121/10.0001631

Seasonal trends and primary contributors to the low-frequency soundscape of the Cordell Bank National Marine Sanctuary

The Journal of the Acoustical Society of America 148, 845 (2020); https://doi.org/10.1121/10.0001726

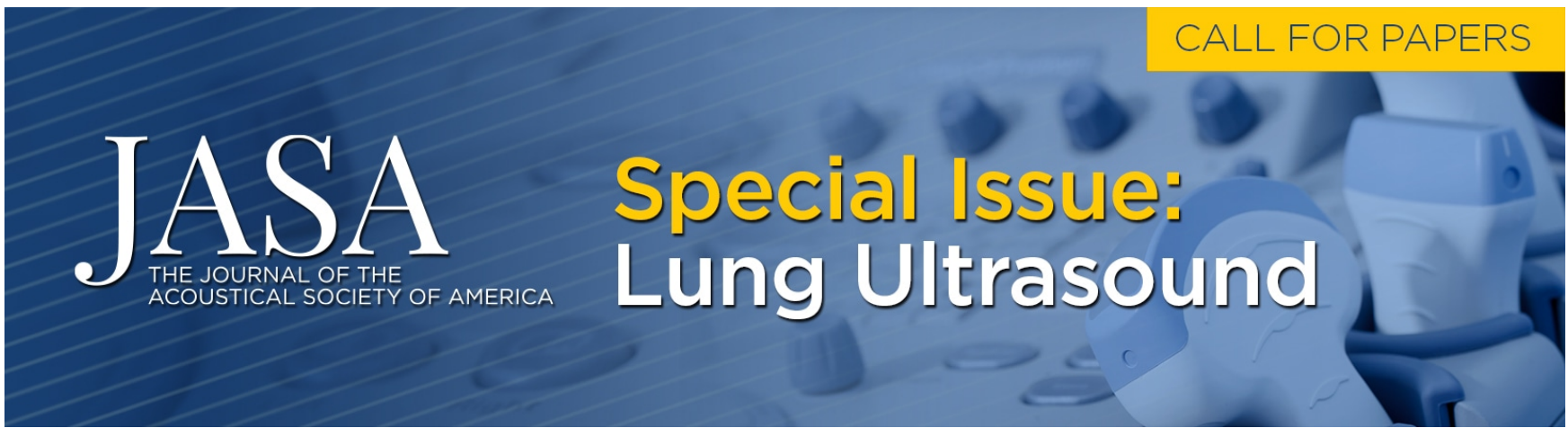




\title{
Predicting the exposure of diving grey seals to shipping noise ${ }^{\text {a) }}$
}

\author{
Leah E. Trigg, ${ }^{1, b)}$ Feng Chen, ${ }^{1}$ Georgy I. Shapiro, ${ }^{1}$ Simon N. Ingram, ${ }^{1}$ Cécile Vincent, ${ }^{2}$ David Thompson, ${ }^{3}$ \\ Debbie J. F. Russell, ${ }^{3, \mathrm{c})}$ Matt I. D. Carter, ${ }^{3, \mathrm{~d})}$ and Clare B. Embling ${ }^{1}$ \\ ${ }^{1}$ School of Biological and Marine Sciences, University of Plymouth, Plymouth PL4 8AA, United Kingdom \\ ${ }^{2}$ Centre d'Etudes Biologiques de Chizé, CNRS/University of La Rochelle, La Rochelle, France \\ ${ }^{3}$ Sea Mammal Research Unit, University of St Andrews, St Andrews, Fife KY16 8LB, United Kingdom
}

\begin{abstract}
:
There is high spatial overlap between grey seals and shipping traffic, and the functional hearing range of grey seals indicates sensitivity to underwater noise emitted by ships. However, there is still very little data regarding the exposure of grey seals to shipping noise, constraining effective policy decisions. Particularly, there are few predictions that consider the at-sea movement of seals. Consequently, this study aimed to predict the exposure of adult grey seals and pups to shipping noise along a three-dimensional movement track, and assess the influence of shipping characteristics on sound exposure levels. Using ship location data, a ship source model, and the acoustic propagation model, RAMSurf, this study estimated weighted 24-h sound exposure levels $(10-1000 \mathrm{~Hz})\left(S E L_{w}\right)$. Median predicted 24-h $S E L_{w}$ was 128 and $142 \mathrm{~dB}$ re $1 \mu \mathrm{Pa}^{2}$ s for the pups and adults, respectively. The predicted exposure of seals to shipping noise did not exceed best evidence thresholds for temporary threshold shift. Exposure was mediated by the number of ships, ship source level, the distance between seals and ships, and the at-sea behaviour of the seals. The results can inform regulatory planning related to anthropogenic pressures on seal populations. (C) 2020 Acoustical Society of America. https://doi.org/10.1121/10.0001727
\end{abstract}

(Received 30 December 2019; revised 10 July 2020; accepted 20 July 2020; published online 26 August 2020)

[Editor: Brian Branstetter]

Pages: 1014-1029

\section{INTRODUCTION}

Global commercial shipping underpins trade and economic development, and with the globalisation of manufacturing and financial markets, shipping has increased dramatically since the start of the 20th century (Hoffmann and Kumar, 2010). The carrying capacity of the world commercial fleet has increased by $1.6 \times 10^{9}$ deadweight tonnes since 1970 and was carried by more than 94000 ships in 2018 (UNCTAD, 2018). Commercial ships emit low frequency underwater noise from propeller cavitation, machinery onboard the ship, and the flow of water past the vessel (Urick, 1983). This has been linked to a $3.3 \mathrm{~dB}$ per decade increase in underwater ambient sound levels between 1950 and 2007 (Frisk, 2012). An increasing weight of evidence suggests that shipping noise, defined as water-borne sound (ISO, 2017) from motorised watercraft (Erbe et al., 2019), can have a detrimental effect on marine mammals through mechanisms such as communication masking (Hatch et al., 2012; Jensen et al., 2009), behavioural change (Blair et al., 2016; Dyndo et al., 2015; Mikkelsen et al., 2019), and physiological changes such as hearing damage (Finneran, 2015; Jones et al., 2017; Rolland et al., 2012).

\footnotetext{
a) This paper is part of a special issue on The Effects of Noise on Aquatic Life.

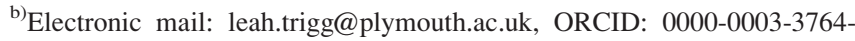
7003

c) ORCID: 0000-0002-1969-102X.

${ }^{d)}$ ORCID: 0000-0002-5481-6254.
}

As central-place foragers that return to haul-out sites to rest, breed, and moult, seals heavily utilise the coastal zones that are also home to busy shipping lanes. Jones et al. (2017) highlighted a high rate of daily co-occurrence for harbour seals, grey seals, and shipping within $50 \mathrm{~km}$ of the coast. Evidence suggests that seals can flush into the water when cruise ships pass haul-out sites (Jansen et al., 2015), and exhibit alert and orienting behaviour in response to the sound of boat playbacks (Tripovich et al., 2012). In addition, Mikkelsen et al. (2019) report $2.2 \%-20.5 \%$ of the atsea time of tagged grey and harbour seals in the North Sea contained audible shipping noise.

However, there is still very little information about the at-sea exposure of seals to shipping noise and their spatial relationship with shipping given their three-dimensional use of the underwater environment. Grey seals (Halichoerus grypus) frequently dive $\sim 200 \mathrm{~m}$ to the seafloor of the continental shelf, although where habitat permits, they can exceed this depth (Jessopp et al., 2013; McConnell et al., 1999; SCOS, 2018; Photopoulou et al., 2014; Thompson et al., 1991). Evidence suggests that they can potentially experience differential noise exposure of up to $10 \mathrm{~dB}$ as they undertake such movement vertically throughout the water column (Chen et al., 2017). To assess noise from shipping, predictions primarily take the form of twodimensional maps (Erbe et al., 2014). However, these maps often neglect or average the influence of depth. This may be particularly problematic when assessing the exposure of seals in shallow shelf seas, which are regions of intersection 
between dynamic environmental properties that influence sound propagation and high density shipping (Simpson and Sharples, 2012).

Phocid seals have a functional hearing range from $50 \mathrm{~Hz}$ to $80 \mathrm{kHz}$ (National Marine Fisheries Service, 2018), which overlaps with the dominant frequencies of noise from large commercial ships $(10-1000 \mathrm{~Hz})$. Seals utilise sound production and reception during mating, mother-offspring interactions, and while maintaining territory (Hayes et al., 2004; Van Parijs et al., 2001). Grey seals vocalise at frequencies between 100 and $500 \mathrm{~Hz}$ (Asselin et al., 1993) placing them at risk of communication masking by shipping noise (Bagočius, 2014). Exposure to underwater noise from shipping has the potential to induce temporary or permanent threshold shift, exhibited by an increase in the threshold level at which an animal can hear at a given frequency (Southall et al., 2007; Southall et al., 2019). The mean daily sound exposure level measured at the Port of Vancouver's inbound shipping lane and weighted using a frequency weighting function for underwater phocid pinnipeds was 156 [standard deviation $(\mathrm{SD})=1.3$ ] $\mathrm{dB}$ re $1 \mu \mathrm{Pa}^{2} \mathrm{~s}$ (Martin et al., 2019), which did not exceed the $181 \mathrm{~dB}$ re $1 \mu \mathrm{Pa}^{2} \mathrm{~s}$ threshold for the onset of temporary threshold shift (TTS) from non-impulsive underwater noise (ISO, 2017; Southall et al., 2019). However, these measurements did not consider seal habitat use. Jones et al. (2017) modelled the exposure of harbour seals in the Moray Firth, Scotland, UK, to shipping noise using seal tag movement data and reported that when considering upper confidence intervals some estimates did exceed the threshold for the onset of TTS. These predictions were only based on the two-dimensional location of seals at-sea and suggest there is still great uncertainty associated with sound exposure predictions.

In response to evidence of the negative impact of underwater noise on marine mammals, a number of international regulatory bodies are taking steps to mitigate the risks associated with shipping noise (European Commission, 2008, 2010, 2017). However, effective management is still constrained by a lack of data pertaining to the exposure of marine life to shipping noise. As a result, it is difficult for policy to set targets for acceptable noise levels without data on historical and current noise levels against which to track trends and measure the effectiveness of policy to mitigate noise (Merchant et al., 2016). It is necessary to understand the exposure of an individual, and consequently populations, in order to explore the impact of this exposure on marine animals (Merchant, 2019; Van der Graaf et al., 2012).

Consequently, this study aims to predict the exposure of individual seals to shipping noise using a sophisticated underwater acoustic propagation model and the threedimensional location and dive tracks of tagged grey seals. Specifically, the study aims to investigate the at-sea exposure of grey seals at two different life stages: pups and adults. The seal tracking data will link noise exposure directly to at-sea vertical and horizontal spatial use by seals, improving the applicability of the results to risk calculations and marine spatial planning. The study also aims to investigate the influence of ship source level, the number of ships, and the proximity of ships to seals on predicted noise exposure levels.

\section{METHODOLOGY}

This study undertook a historical reconstruction of 24-h weighted sound exposure levels $\left(S E L_{w}\right)$ (ISO, 2017) for seal pups in the Celtic Sea and adult seals primarily located in the English Channel with respect to shipping noise (Fig. 1). These regions host high volume shipping lanes (Fig. 2) but grey seals also utilise breeding and haul-out sites along the coast, resulting in significant overlap between grey seals and shipping (Jones et al., 2017; SCOS, 2018). The region is a good example of a dynamically active, shallow, shelf sea characterised by mesoscale eddies and fronts, as well as the development of a strong thermocline in the summer (Pingree, 1980), and the influence these properties have on sound propagation (Shapiro et al., 2014). Seals were tagged with Fastloc $₫$ Global Positioning System/Global System for Mobile Communication (GPS/GSM) tags (SMRU Instrumentation), which provided location and dive data for each seal. The seals were tagged as part of separate studies on animal movement and habitat use from 2009 to 2013 (Huon et al., 2015; Thompson, 2012). Weighted sound pressure levels (SPLs) (ISO, 2017) from ships in a $24 \mathrm{~h}$ period were predicted along each seal's three-dimensional track using historic records of ship movements, a ship source level model and a range dependent acoustic propagation model.

\section{A. Seal location and movement data}

The details of 18 seals included in the study are given in Table I. Celtic Sea animals were tagged in 2009 or 2010 at sites on Anglesey or Ramsey Island, Wales, UK (Table I, Fig. 1) under Home Office Licence No. 60/4009. English Channel animals were tagged in the Iroise Marine Park under licence Nos. 10/102/DEROG and 13/422/DEROG provided by the French Ministry of the Environment (Fig. 1). Seals were caught, anaesthetised using Zoletil® (Vibrac, France) where necessary, and tags were glued to clean, dry fur at the base of the neck using epoxy resin or cyano-acrylate contact adhesive. The tagging methodology followed McConnell et al. (1999) and is explained in detail by Thompson (2012, p. 6), Huon et al. (2015, p. 1093), and Carter et al. (2017).

Erroneous GPS locations were identified as those obtained using fewer than five satellites and/or having high residual error values from the Fastloc ${ }^{\circledR}$ position algorithm (Dujon et al., 2014; Russell and McConnell, 2014). These were removed, and tests on land reveal that such procedures can result in a distance error $<50 \mathrm{~m}$ for $95 \%$ of locations (Russell and McConnell, 2014). An animal was given the status "diving" when the tag registered a depth of $1.5 \mathrm{~m}$ or deeper for greater than $8 \mathrm{~s}$. A dive ended when depth was shallower than $1.5 \mathrm{~m}$. In order to produce a threedimensional track for each seal, the timestamps of location and depth points transmitted by the tags were used to interpolate each dive in space using hermite curve interpolation 


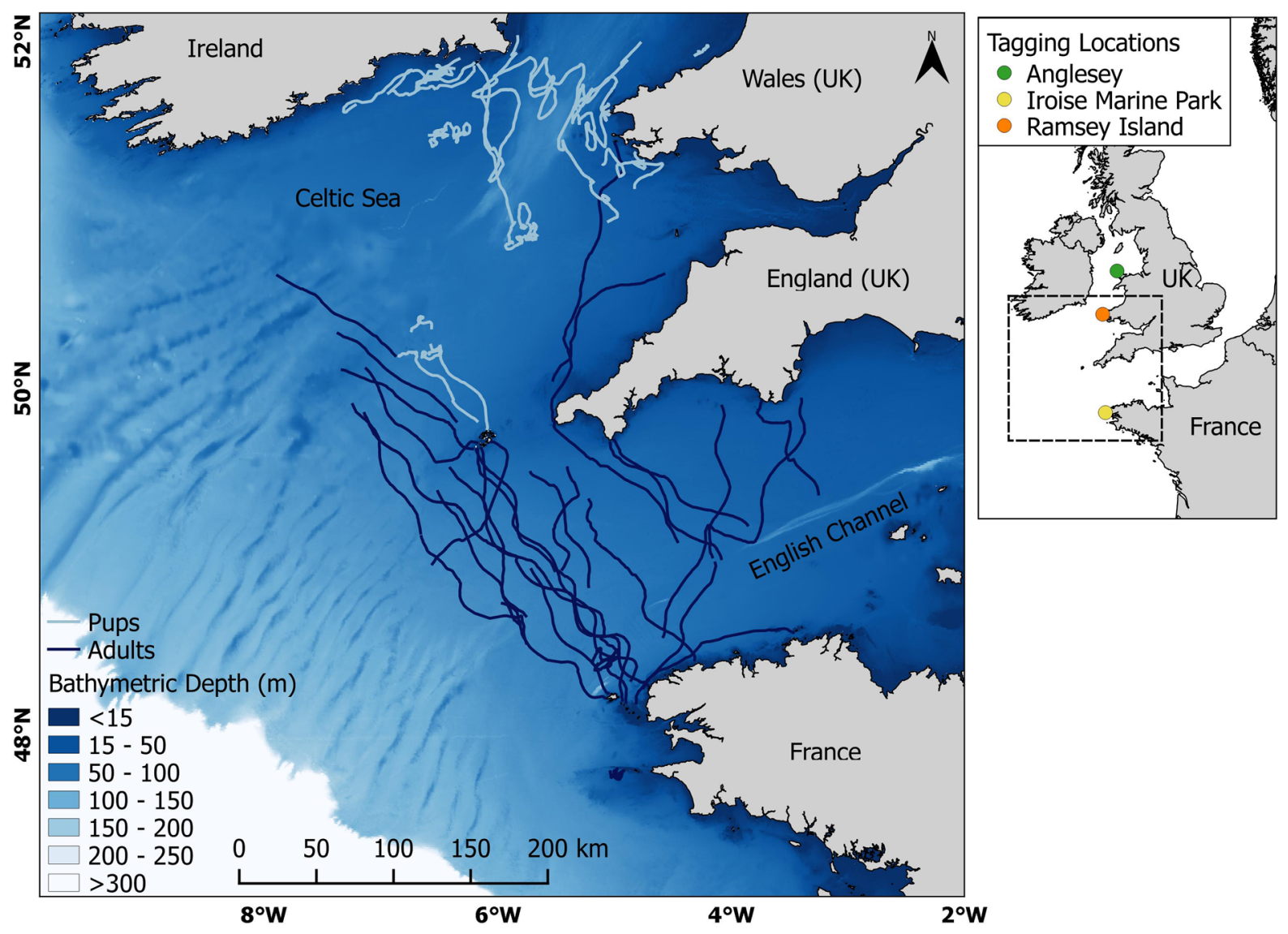

FIG. 1. (Color online) Map of study area showing the bathymetric depth of region and $24 \mathrm{~h}$ seal track segments used to calculate weighted sound exposure levels. Navy blue tracks are adult seals tagged in the Iroise Marine Park (Inset map: yellow dot). Light blue tracks are seal pups tagged on Anglesey (Inset map: green dot) or Ramsey Island (Inset map: orange dot), Wales, UK.

(Kuhn et al., 2010; Tremblay et al., 2006). The tags attempt to record regular location fixes but they rely on the seal surfacing to capture satellite data (Carter et al., 2016). As a result, the time between location points can vary, and there can be bias in the number of GPS points to locations where the seal is not diving. To address this, the interpolation also re-sampled the seal track at a rate of $1 \mathrm{~s}$ to produce a track with regularly spaced location points. Hermite curve interpolation can more closely represent the curvilinear paths of animals moving through a fluid environment than linear interpolation (Tremblay et al., 2006). Dives that were not within 180 min of a GPS fix were excluded to reduce error in interpolated locations (Carter et al., 2017). This value retains as much continuous track as possible while limiting error.

In order to calculate at-sea 24-h sound exposure levels, periods of haul-out were excluded and track segments that were $24 \mathrm{~h}$ in duration were extracted. Haul-outs were determined by the wet/dry sensors aboard the tag and periods of haul-out were transmitted as part of the tag data message. In addition, track segments had to be located entirely within the study area to ensure Automatic Identification System (AIS) data coverage and overlap in time and space with environmental datasets for acoustic modelling. The 24-h track segments along which noise was estimated are shown in Fig. 1 and the number of days processed for each seal is shown in Table I. The mean maximum dive depth and mean inter-dive interval for all seals was $34.7(\mathrm{SD}=32.8) \mathrm{m}$ and $58.1(\mathrm{SD}=51.4)$ seconds, respectively.

\section{B. Ship location data}

This study utilised historical data from terrestrial AIS to determine the location of ships at sea in relation to the grey seal tracks. AIS data were obtained from ShipAIS (ShipAIS, 2018) and Marine Traffic for time periods that overlap with the seal data. Each dataset provided coverage for a subsection of the total study area (Fig. 1), but overall this resulted in complete coverage of the area (Figs. 1 and 2). The data from all sources were combined in a SQLite database and matched on the unique field "MMSI number."

A subset of 930 MMSI numbers were removed from the analysis because no data on vessel length was available; length was recorded as zero or they were identified as base stations and aircraft, resulting in 22443 ships in the final AIS database. The data were split into transects. A transect was defined as containing more than one AIS location point, and the ship was moving at a speed over ground over 1.5 knots. Ships slower than this were likely to be stationary or drifting at anchor (Marine Management Organisation, 2014, 2015). A transect ended and a new transect started when 


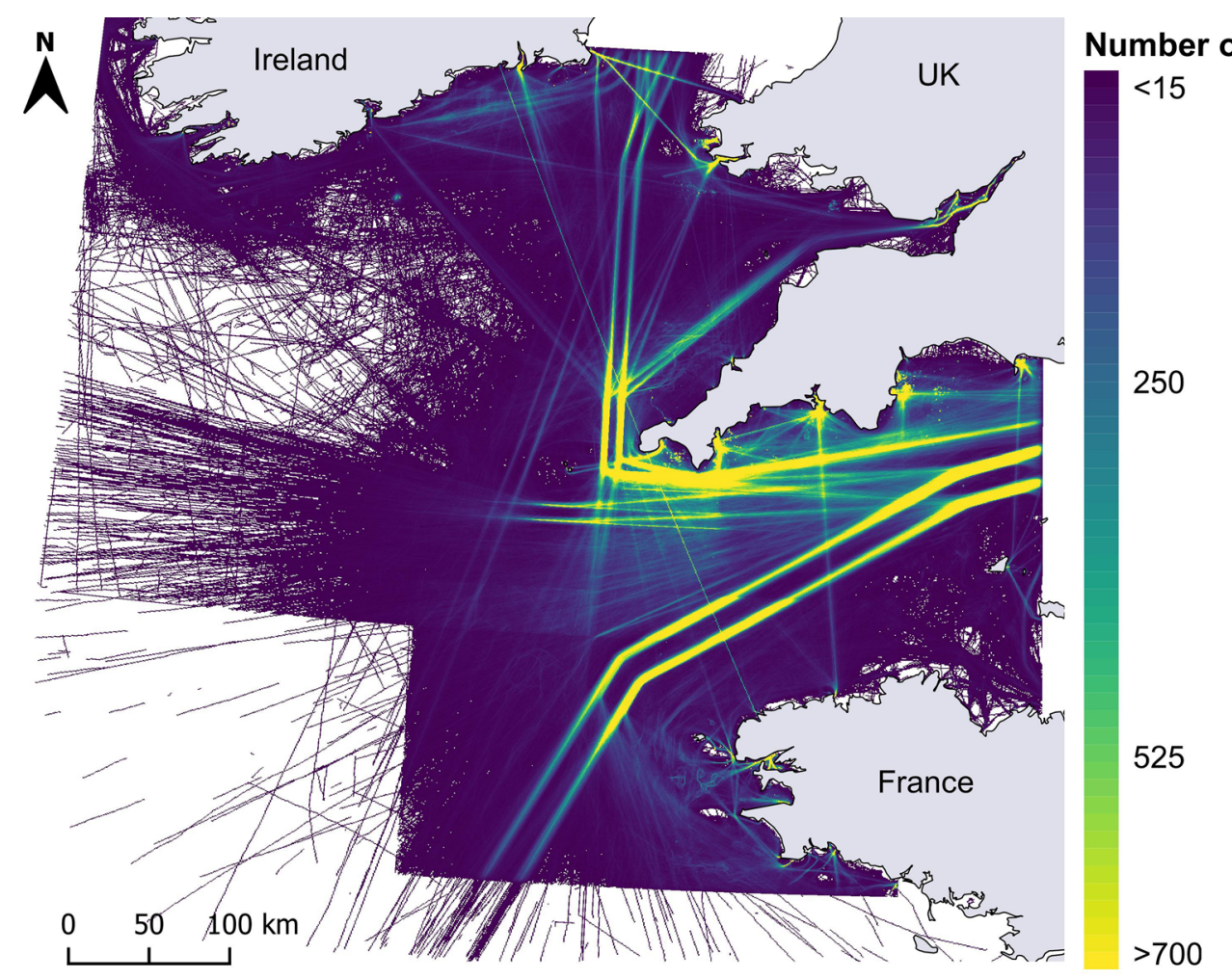

FIG. 2. (Color online) Ship transects derived from raw AIS data from all data sources. Shows AIS data coverage of area occupied by the seal tracks. Colour ramp shows total number of transects that intersect a cell for all data (approximately $1 \mathrm{~km} \times 1 \mathrm{~km}$ ). Data between $2 \%$ and $98 \%$ of range visualised. Transects are passages of a ship with more than 1 AIS location point, travelling at a speed over ground between 1.5 and $60 \mathrm{knots}$ and with less than 180 min between points. Maximum number of transects passing through a cell was 352690 .

there was greater than $180 \mathrm{~min}$ between location points. The next point was the start of a new transect. This 180 min time interval was short enough to resolve ships rounding Land's End, UK, and heading north into the Celtic Sea, as well as

TABLE I. Details of seal tag data used in the study. A total of 18 seals were included; nine adults and nine pups. Noise was calculated for a total of 86 days. The table shows the percentage of the total time the seal spent at sea used in the study. ISMP, Iroise Sea Marine Park.

\begin{tabular}{lcccccc}
\hline \hline ID & $\begin{array}{c}\text { Location } \\
\text { tagged }\end{array}$ & $\begin{array}{c}\text { Mass } \\
(\mathrm{kg})\end{array}$ & Sex & $\begin{array}{c}\% \text { track } \\
\text { used }\end{array}$ & Days & $\begin{array}{c}\text { Age } \\
\text { Class }\end{array}$ \\
\hline B23 & ISMP & 129 & M & 3.4 & 4 & Adult \\
B24 & ISMP & 124 & M & 4.8 & 6 & Adult \\
B26 & ISMP & 68 & $\mathrm{~F}$ & 0.6 & 1 & Adult \\
B27 & ISMP & 152 & M & 2.4 & 4 & Adult \\
B31 & ISMP & 206 & M & 4.0 & 4 & Adult \\
B32 & ISMP & 114 & $\mathrm{~F}$ & 3.4 & 4 & Adult \\
B33 & ISMP & 210 & M & 7.3 & 11 & Adult \\
B35 & ISMP & 148 & M & 3.5 & 4 & Adult \\
B37 & ISMP & 70 & M & 3.8 & 4 & Adult \\
hg27-01-09 & Anglesey & 37 & M & 2.1 & 3 & Pup \\
hg27-04-09 & Anglesey & 38 & M & 3.3 & 5 & Pup \\
hg29-11-10 & Anglesey & 35 & M & 2.0 & 5 & Pup \\
hg29-15-10 & Ramsey & 39 & $\mathrm{~F}$ & 0.5 & 1 & Pup \\
hg29-16-10 & Anglesey & 40 & $\mathrm{~F}$ & 4.4 & 5 & Pup \\
hg29-18-10 & Ramsey & 32 & M & 10.6 & 9 & Pup \\
hg29-21-10 & Ramsey & 37 & M & 5.5 & 7 & Pup \\
hg29-23-10 & Ramsey & 29 & M & 5.3 & 1 & Pup \\
hg29-24-10 & Ramsey & 32 & F & 25.8 & 8 & Pup \\
\hline \hline
\end{tabular}

J. Acoust. Soc. Am. 148 (2), August 2020 those leaving and returning to the study area, while retaining the presence of as many ships as possible. The location of a ship along the transect at a particular time was estimated using linear interpolation.

\section{Ship source model}

The source level (ISO, 2017) of each ship was calculated using the Research Ambient Noise Directionality (RANDI) model (Breeding et al., 1996; Chen et al., 2017; Erbe et al., 2014; Jones et al., 2017; Ross, 1976; Williams et al., 2014). The model is based on the relationship between ship source level, speed, and vessel length and has a satisfactory agreement with monopole source levels (ISO, 2019) derived from measured data. RANDI has exhibited underestimates of 5-13 dB at frequencies greater than $200 \mathrm{~Hz}$ (Simard et al., 2016), and median estimation errors of 0 ( $\pm 7.1 \mathrm{~dB}$ ) (Peng et al., 2018) when compared to monopole source levels. There are several ship source level models available (Brooker et al., 2015; Wittekind, 2014) and each of these models exhibit some level of disagreement (Jansen and de Jong, 2017; Karasalo et al., 2017; Simard et al., 2016) when compared to monopole source levels derived from measured data (Chion et al., 2019; ISO, 2017). Given this variation between models, a deterministic one-way sensitivity analysis was conducted to assess the influence of source level and other modelling parameters on the predicted exposure of seals. The resulting uncertainty in predicted exposure was calculated by generating bootstrapped 
samples of $S E L_{w}$ every $15 \mathrm{~min}$ along the seal track. A more detailed explanation of this analysis is included in the Supplemental Material. ${ }^{1}$

The length and speed of the ship for input into the RANDI model was derived from the AIS data. Spectral source levels were estimated at every $1 \mathrm{~Hz}$ between 10 and $1000 \mathrm{~Hz}$ and integrated to give $1 / 3$ octave band source levels (ISO, 2017). The 1/3 octave band source level was obtained for each ship individually in a 15 min period using the ship's length and speed over ground at that point along its transect. Median broadband source levels in the database ranged from $132 \mathrm{~dB}$ re $1 \mu \mathrm{Pa}^{2} \mathrm{~m}^{2}$ for ships $<30 \mathrm{ft}$ to $196 \mathrm{~dB}$ re 1 $\mu \mathrm{Pa}^{2} \mathrm{~m}^{2}$ for ships $>630 \mathrm{ft}$. Ship source levels were not grouped into classes.

\section{Acoustic propagation model}

The parabolic equation model RAMSurf (Collins, 1993) was used to calculate propagation loss (ISO, 2017) between each sound source and the location of each seal. This model is suitable for range dependent, low frequency, shallow water scenarios (Etter, 2013). The horizontal and vertical step parameters for the acoustic model were fixed at 50 and $0.5 \mathrm{~m}$, respectively, for all simulations. These ensured a convergent solution across all frequencies tested. Ships greater than $164 \mathrm{ft}$ ( $\sim 50 \mathrm{~m})$ were assigned a source depth of $6 \mathrm{~m}$ (Scrimger and Heitmeyer, 1991) and smaller vessels a depth of $3 \mathrm{~m}$ (Erbe et al., 2012b). The model considers detailed three-dimensional environmental changes. The environmental conditions were described along each transect by submitting the bathymetric depth, a sound speed profile for the water column, and geoacoustic parameters every $2 \mathrm{~km}$ to the maximum range of each transect. Sediment type was determined from the EMODnet Geology project seabed substrate map (1:1 000 000) (European Commission, 2016). Geoacoustic parameters for the model were extracted from the literature based on the percentage of mud, sand, and gravel given in the sediment classification (Hamilton, 1980; Long, 2006). The sound speed profile was calculated using the nine-term equation proposed by Mackenzie (1981). Temperature and salinity values for each profile were extracted from the Iberian Biscay Irish Ocean Reanalysis system $(0.083 \times 0.083$ degrees resolution; 50 depth levels) available through the E.U. Copernicus Marine Environment Monitoring Service (CMEMS; product identifier: IBI_REANALYSIS_PHYS_005_002). Complete tables of model and geoacoustic parameters are given in the Supplemental Material. ${ }^{1}$

The bathymetry of UK and Irish waters was determined using the EMODnet Digital Bathymetry (DTM 2016) at $1 / 8 * 1 / 8$ arc min resolution (EMODnet Bathymetry Consortium, 2016). This data is given in metres with reference to lowest astronomical tide but converted to mean sea level using the Vertical Offshore Reference Frame data generated by the UK Hydrographic Office (Adams et al., 2006; Turner et al., 2010). Bathymetric data for French waters were taken from the MNT Bathymétrique de facade
Atlantique (Projet Homonim), which is provided in metres with reference to mean sea level (Shom, 2015).

Seal tag data provides depth with reference to the water surface. This varies in height with respect to the sea floor throughout the tidal cycle. The seals are diving throughout the tidal cycle and, therefore, can dive deeper than the bathymetry layer at certain points. This was minimised by using bathymetry with reference to mean sea level and noise exposure values were corrected to the noise level $5 \mathrm{~m}$ above the sea floor if there was a mismatch between maximum dive depth and bathymetric depth. The impact of this correction was assessed within the sensitivity analysis presented in the Supplemental Material. ${ }^{1}$

Simulations were conducted at the centre frequencies of one-third octave bands between 10 and $1000 \mathrm{~Hz}$. This frequency range encompasses the maximum energy output for ships and covers both of the frequencies (63 and $125 \mathrm{~Hz}$ ) recommended by the Marine Strategy Framework Directive as important for monitoring shipping noise (European Commission, 2008, 2010, 2017). However, it is noted that ship source levels do extend beyond this (Veirs et al., 2015). The propagation loss output was smoothed to remove variation associated with the coherent nature of the model. This was completed using a moving average (Harrison and Harrison, 1995).

\section{E. Construction of three-dimensional received noise levels}

At each 15 min time step, a three-dimensional noise field of broadband $(10-1000 \mathrm{~Hz})$ weighted SPL $\left(S P L_{w}\right)($ ISO, 2017) was generated for the area enclosing the dive and location track of the seal (Fig. 3). SPLs (ISO, 2017) for each ship were calculated by subtracting smoothed propagation loss values, calculated using the RAMSurf model, from the ship source levels, calculated using the RANDI ship source model. The RAMSurf model output is two-dimensional (range and depth). Three-dimensional coverage of the area enclosing the seal track was generated by calculating propagation loss along multiple transects at an azimuth of $2.5^{\circ}$. This produced a noise field composing depth and range at multiple azimuths (Fig. 3). SPLs were weighted using two methods: the underwater mweighting function proposed by Southall et al. (2007) for pinnipeds and the underwater frequency weighting function for phocid pinnipeds proposed by Southall et al. (2019). Broadband $S P L_{w}(10-1000 \mathrm{~Hz})$ was calculated by integrating across all frequencies (approximated by summation). Total $S P L_{w}(10-1000 \mathrm{~Hz})$ from all ships at each point along the seal track was calculated by summing the noise intensity of each ship as shown in Eq. (1), where $l_{i}$ is the $i$ th ship and $n$ is the number of ships in $15 \mathrm{~min}$,

$$
\operatorname{totalSPL}_{w}=10 \log _{10} \sum_{i=1}^{n} 10^{l_{i} / 10} .
$$

The ship locations were determined for the mid-point of each 15 min time period. The ships were assumed to remain 


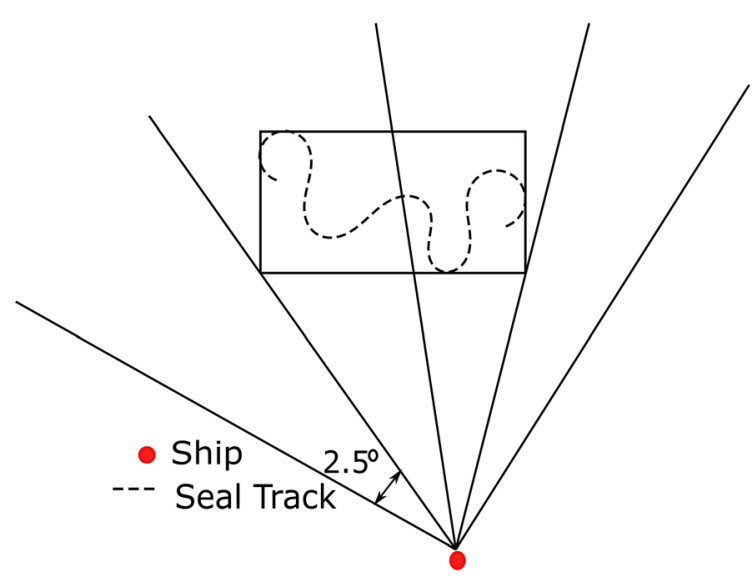

(a)

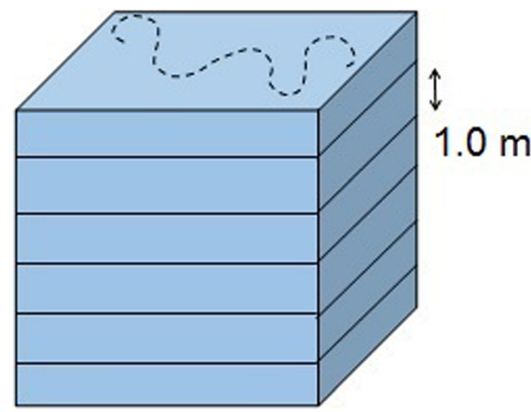

(b)

FIG. 3. (Color online) Diagram of methodology used to create the received noise field for each 15 min of seal track. For each 15 min track segment, the track was enclosed in a rectangle. For each ship, the bearing between the ship and corners of the rectangle were calculated. The maximum bearing was increased and the minimum bearing was decreased by $2.5^{\circ}$ to ensure complete coverage of the seal track and transects between the two outer transects were created at an azimuth of $2.5^{\circ}$. Propagation loss and hence received SPLs were calculated along each transect and at every $1 \mathrm{~m}$ in depth. (a) Top view; (b) depth view.

stationary during each $15 \mathrm{~min}$ period and the seal moved throughout the noise field. It is recognised that in reality, the ships and seals would move relative to each other in a 15 min period. However, the computational time required to recalculate the sound field using the RAMSurf model is a key factor in determining the possible temporal resolution for noise calculations. This parameter was included in a sensitivity analysis (see Supplemental Material ${ }^{1}$ ) that demonstrated the sufficient accuracy of a 15 min resolution.

All ships within $120 \mathrm{~km}$ of the seals' location in a 15 min period were included in noise calculation estimates. It was a precautionary threshold to include all possible ships contributing to noise levels. Seals located close to the boundary would be exposed to fewer ships due to the lack of AIS data outside the boundary. To combat this issue, a $15 \mathrm{~km}$ buffer zone was implemented. Seal tracks only touched the edge of the $15 \mathrm{~km}$ buffer zone on 5 of 86 days.

\section{F. 24-h sound exposure levels and prediction of auditory damage}

The exposure of the seal to shipping noise was linearly interpolated from the sound field for each 24-h period to give sound exposure levels with a temporal resolution of $1 \mathrm{~s}$ (i.e., a noise exposure value was predicted at the seal's location every $1 \mathrm{~s}$ ). The temporal exposure period of $24 \mathrm{~h}$ is arbitrary (National Marine Fisheries Service, 2018; Southall et al., 2019). However, this is the standard cumulative period utilised by National Marine Fisheries Service (2018) for assessing auditory threshold shift.

Sound exposure has the potential to have a negative impact on auditory systems through permanent threshold shift or temporary threshold shift, as well as instigate maladaptive behavioural or physiological responses (Hastie et al., 2018; Rolland et al., 2012; Southall et al., 2019). Consequently, this study reports two sound exposure values, 24-h $S E L_{w}$ and 24-h $S E L_{w}$ above effective quiet. The 24-h $S E L_{w}$ represents the total contribution of shipping noise perceivable by seals to the soundscape (ISO, 2017) (given the limitations in AIS data) and includes weighted SPLs emitted by ships that, while may not be at an intensity to cause auditory damage, may be pertinent in assessing behavioural responses to noise levels or when assessing the contribution of shipping to the wider soundscape. The 24-h $S E L_{w}$ above effective quiet was calculated by removing $S P L_{w}$ values below an estimated level of effective quiet for grey seals, $124 \mathrm{~dB}$ re $1 \mu \mathrm{Pa}^{2}$ (Finneran, 2015). Effective quiet can be defined as the exposure levels which neither result in TTS nor retard the recovery of TTS from a previous exposure (Ward et al., 1976). It recognises that some sound exposures are at a level that no matter how long the exposure lasts, it will never result in TTS (Ward et al., 1976). It is important to consider the effective quiet threshold when calculating sound exposure levels because accumulating low sound levels over long durations may result in an inflated impression of sound levels (Finneran and Branstetter, 2013). However, there is very little data on appropriate levels of effective quiet in marine mammals (Finneran, 2015). Hence, the value used here was estimated by Finneran (2015) when considering the lowest value known to cause TTS in pinnipeds. The two types of sound exposure levels were weighted using the Southall et al. (2007) frequency weighting function and compared to the best estimate value of $183 \mathrm{~dB}$ re $1 \mu \mathrm{Pa}^{2}$ s for the onset of TTS in pinnipeds with respect to non-impulsive sounds (Southall et al., 2007). For comparison, they were also weighted using the updated frequency weighting function proposed by Southall et al. (2019) and compared to the corresponding threshold of $181 \mathrm{~dB}$ re $1 \mu \mathrm{Pa}^{2} \mathrm{~s}$ for the onset of TTS in phocid pinnipeds (Southall et al., 2019). Uncertainty estimates associated with modelled values are provided in the Supplemental Material. ${ }^{1}$ 


\section{G. Analysis of shipping traffic}

The relative influence of ship source levels, distance, and the number of ships on the calculated sound exposure levels from shipping was analysed using a Generalised Additive Mixed Model (GAMM). GAMMs allows for nonlinear relationships between the response variable and the explanatory variables and the inclusion of random effects. The response variable, 15 -min $S E L_{w}$ (i.e., $S E L_{w}$ integrated over $15 \mathrm{~min}$ and weighted using frequency weighting function proposed by Southall et al., 2007), was modelled using the explanatory variables, closest point of approach of a ship (CPA), defined as the minimum separation distance between a seal and any of the ships in the 15 min section, the maximum source level of any ship in the $15 \min \left(S L_{\max }\right)$, the number of ships within $120 \mathrm{~km}$ of the seal for those $15 \mathrm{~min}$ (NUM), and the location of the seal (English Channel or Celtic Sea). CPA, NUM, and $S L_{\max }$ were included in the model as individual smooths as well as a multivariate smoothed term using tensor product smooths of cubic regression splines (Wood, 2006). This was appropriate because each covariate was not isotropic (i.e., they did not have the same scale) (Wood, 2006). The GAMM models were implemented in R version 3.5.3 (R Core Team, 2019) using the mgcv package version 1.8-28 (Wood, 2003, 2004, 2006). The models were implemented using a Gaussian error structure with an identity link function. The response variable was $\log$ transformed $[\log (y)]$ to improve the normality of the residuals where different model families (e.g., Gamma) did not improve the model.

The random variable seal was included to account for the possibility of greater similarity between the exposures of an individual seal compared to other seals. Each $15 \mathrm{~min}$ sample was highly autocorrelated because it was likely to contain the same ships as those before and after it. As a result, the data were subsampled and every tenth $15 \mathrm{~min}$ section was included in the model. The inclusion of a spherical correlation structure $[$ corSpher $($ form $=\sim 1 \mid$ seal $)]$ reduced any remaining autocorrelation between the residuals where necessary. Model selection was completed using Akaike's Information Criterion (AIC) and followed the methodology laid out by Zuur (2009) by first creating a model with all variables, determining the random structure that gave the lowest AIC and then determining the optimum fixed effects structure by removing variables and comparing AIC values. AIC was given by -2 loglikelihood $+2 k$, where $k$ is the number of parameters. Model validation was completed by visual inspection of the residuals.

\section{RESULTS}

\section{A. Shipping traffic and seals}

The weighted sound exposure levels of adult grey seals in the English Channel and grey seal pups in the Celtic Sea varied as they moved throughout their environment, particularly, lower received levels resulted from scattering and absorption at the boundaries with the surface and bottom of the ocean (Figs. 4 and 5). Spatial variation in received noise levels was driven in part by the number of ships, the source level of the ships and the distance between the seal and the ship. In a $15 \mathrm{~min}$ period, within $5 \mathrm{~km}$ of the seal, the mean number of ships was only 1.1 ( $\mathrm{SD}=0.3$ ) for the Celtic Sea and $1.3(\mathrm{SD}=0.5)$ for the English Channel. However, within $120 \mathrm{~km}$ of the seal, this was higher for the English Channel group at $26.9(\mathrm{SD}=24.5)$ ships and lower for the Celtic sea group at $6.5(\mathrm{SD}=7.2)$ ships, highlighting the overall busier nature of the greater English Channel area (Fig. 2).

The CPA between a seal and any of the ships in a 15 min section, was $161 \mathrm{~m}$ for the English Channel seals and $535 \mathrm{~m}$ for the Celtic Sea seals. The majority of $15 \mathrm{~min} \mathrm{sec}-$ tions $(52 \%)$ had a CPA below $35 \mathrm{~km}$. For the English Channel seals $65 \%$ of CPA for ships were below $35 \mathrm{~km}$, whereas ships in the Celtic Sea were generally not as close to the seals and only $41 \%$ of CPA were below $35 \mathrm{~km}$.

The source levels of ships included in the predictions were greater in the English Channel (median $=176 \mathrm{~dB}$ re 1 $\mu \mathrm{Pa}^{2} \mathrm{~m}^{2}$, Inter-Quartile Range, IQR $=46 \mathrm{~dB}$ ) than the Celtic Sea $\left(\right.$ median $=170 \mathrm{~dB}$ re $\left.1 \mu \mathrm{Pa}^{2} \mathrm{~m}^{2}, \mathrm{IQR}=34 \mathrm{~dB}\right)$. This difference was even more stark when only considering those ships that were within $5 \mathrm{~km}$ of the seal. The median source level in the English Channel was $177 \mathrm{~dB}$ re $1 \mu \mathrm{Pa}^{2} \mathrm{~m}^{2}$ $(\mathrm{IQR}=30 \mathrm{~dB})$ but this was only $154 \mathrm{~dB}$ re $1 \mu \mathrm{Pa}^{2} \mathrm{~m}^{2}$ $(\mathrm{IQR}=20 \mathrm{~dB})$ in the Celtic Sea. Seals included in the study in the Celtic Sea, generally utilised areas located further from the major shipping lanes where the largest ships are concentrated (Figs. 1 and 2).

The relationship between 15-min $S E L_{w}$, the CPA of a ship, maximum ship source level $\left(S L_{\max }\right)$, and the number of ships within $120 \mathrm{~km}$ of the seal (NUM) in that 15 min was modelled using a GAMM. The model, following stepwise model selection using AIC, included the multivariate smooth of CPA, NUM, and $S L_{\max }$, as well as the main effect smooths of $S L_{\max }$ and CPA as significant explanatory variables (Table II). It did not include location or the number of ships as an individual smooth (Table II). The 15-min $S E L_{w}$ decreased as the CPA increased, and 15-min $S E L_{w}$ increased as the maximum ship source level increased. As the CPA increased, noise remained constant if the maximum source level increased and/or the number of ships increased. This relationship did not differ between the Celtic Sea or English Channel. However, in the Celtic Sea, there are fewer $15 \mathrm{~min}$ sections with high numbers of ships, a close approach and high $S L_{\max }$ than the English Channel (Fig. 6). Model validation plots are included in the Supplemental Material ${ }^{1}$ and show the residuals and autocorrelation were appropriately modelled.

The relationship between CPA, NUM, and $S L_{\max }$ can be examined more closely in Figs. 4 and 5, which also show the distance between a seal and the ships that were included in the soundscape calculations. Figure 4 shows three peaks in $S P L_{w}$ greater than $105 \mathrm{~dB}$ re $1 \mu \mathrm{Pa}^{2}$ just before 12:06, at 14:53, and between 23:13 and 02:00. The high noise levels at the seal are mediated by the source level of the ship, how 

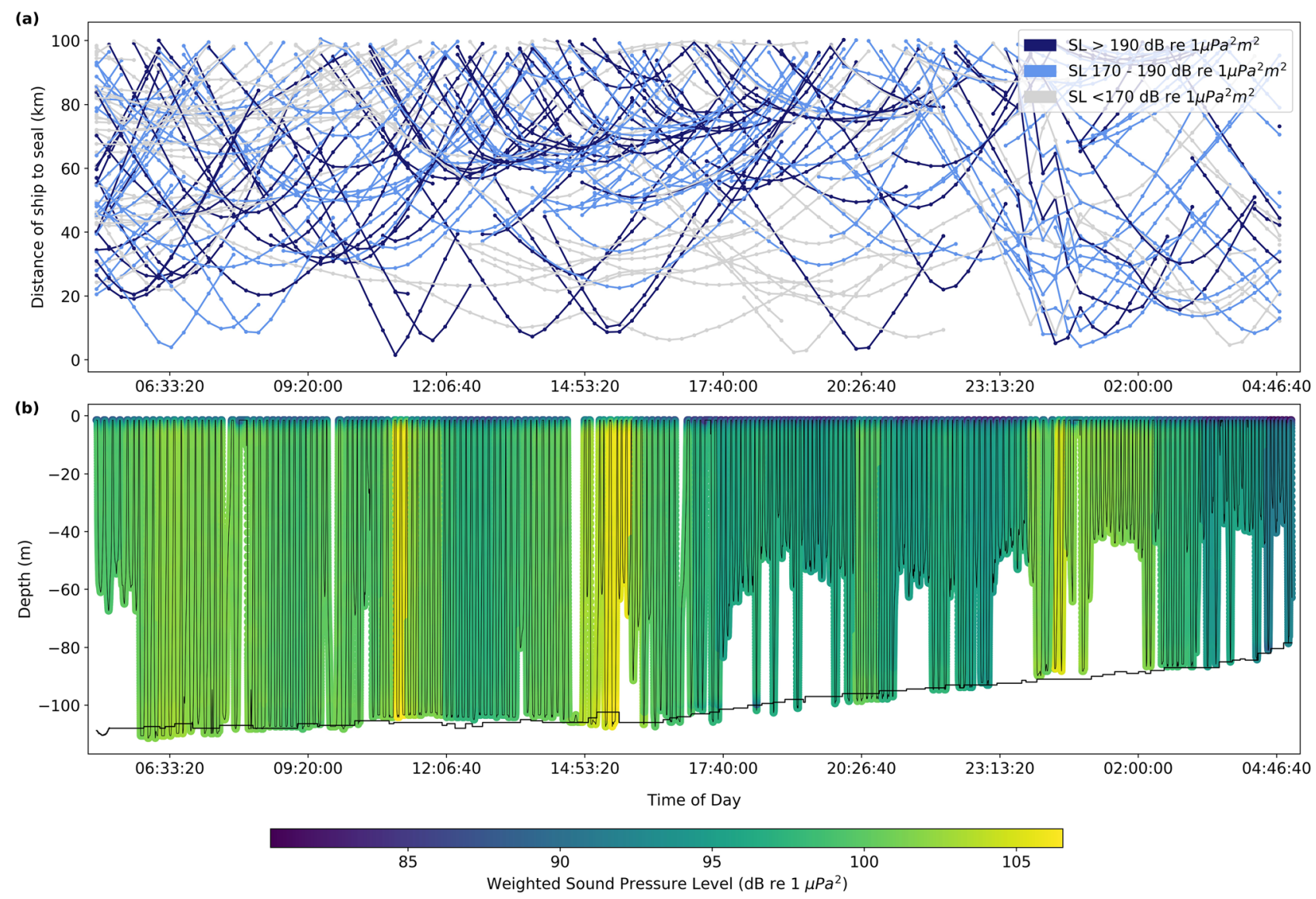

FIG. 4. (Color online) Distance between the seal and each ship (a) and the weighted received SPLs along the dive track of Seal B23 for $24 \mathrm{~h}$ in the English Channel (b). The source level of each ship is classified to show the loudest ships. The noise levels are a reflection of the number of ships, distance between seal and ships, and the source level of each ship. The total number of ships in each source level category was 87,116 , and 93 for $>190,170-190$, and $<170$ $\mathrm{dB}$ re $1 \mu \mathrm{Pa}^{2} \mathrm{~m}^{2}$, respectively. Time of day starts at 29th October 2011 05:05:00. Black horizontal line indicates bathymetry. Black vertical lines indicate seal dives. Values were weighted as proposed by Southall et al. (2019). Dives below the bathymetry arise from bathymetry referenced to mean seal level, the seal diving throughout the tidal cycle, and location error.

close the ship came to the seal, and the number of ships. Just before 12:06 at Peak 1 a loud ship $\left(>190 \mathrm{~dB}\right.$ re $\left.1 \mu \mathrm{Pa}^{2} \mathrm{~m}^{2}\right)$ is close to the seal. At Peak 2 just after 14:53, the ships are further away from the seal than during Peak 1 but there is a second loud ship and the presence of a quieter ship $(<170 \mathrm{~dB}$ re1 $\left.\mu \mathrm{Pa}^{2} \mathrm{~m}^{2}\right)$ in the area, which results in similar overall noise levels at Peak 1 and 2. The peak in noise between 23:13 and 02:00 has a high number of different ships, which results in sustained noise levels across the time despite variation in traffic. At 20:26, a loud ship results in higher noise levels; just before this, a ship follows an almost identical path to the ship at 20:26, but the lower source level of the ship results in lower noise levels.

\section{B. 24-h sound exposure levels}

The 24-h $S E L_{w}$ ranged from 124 to $170 \mathrm{~dB}$ re $1 \mu \mathrm{Pa}^{2} \mathrm{~s}$ for all seals for a total of 86 days (Fig. 7) when weighted using the underwater pinniped frequency weighting function proposed by Southall et al. (2007). Median 24-h $S E L_{w}$ for all seals was $149 \mathrm{~dB}$ re $1 \mu \mathrm{Pa}^{2}$ s. Median 24-h $S E L_{w}$ for the Celtic Sea pups was $143(129-156) \mathrm{dB}$ re $1 \mu \mathrm{Pa}^{2} \mathrm{~s}$ and 159 (124-170) $\mathrm{dB}$ re $1 \mu \mathrm{Pa}^{2} \mathrm{~s}$ for the English Channel adults.
These values represent the total exposure of seals to shipping noise during these $24 \mathrm{~h}$ periods. However, $S P L_{w}$ values throughout the $24 \mathrm{~h}$ ranged from 0 to $140 \mathrm{~dB}$ re $1 \mu \mathrm{Pa}^{2}$ with the median value of the maximum $S P L_{w}$ on each of the 86 days being $115 \mathrm{~dB}$ re $1 \mu \mathrm{Pa}^{2}$. In contrast, 24-h $S E L_{w}$ was between 9 and $18 \mathrm{~dB}$ lower when weighted using the updated underwater frequency weighting function for phocid pinnipeds proposed by Southall et al. (2019). Median 24-h $S E L_{w}$ for the Celtic Sea pups was 128 (118-140) dB re $1 \mu \mathrm{Pa}^{2} \mathrm{~s}$ and $142(106-152) \mathrm{dB}$ re $1 \mu \mathrm{Pa}^{2} \mathrm{~s}$ for the English Channel adults with a maximum $S P L_{w}$ of $121 \mathrm{~dB}$ re $1 \mu \mathrm{Pa}^{2}$ and median maximum $S P L_{w}$ of $99 \mathrm{~dB}$ re $1 \mu \mathrm{Pa}^{2}$ for all seals.

In order to assess if TTS could occur in the seals, 24-h $S E L_{w}$ above effective quiet was also calculated using only exposures to $S P L_{w}$ greater than or equal to the value of effective quiet (124 dB re $\left.1 \mu \mathrm{Pa}^{2}\right)$ in a $24 \mathrm{~h}$ period. For the values weighted as proposed by Southall et al. (2007), the number of days with 24-h $S E L_{w}$ above zero decreased dramatically from 86 to 18 when considering only $S P L_{w}$ greater than or equal to the value of effective quiet. Mean exposure duration above effective quiet was $38.57 \quad(\mathrm{SD}=47.86)$ minutes (Table III). All but one of the days with $S P L_{w}$ above effective quiet were for seals in the English Channel. 24-h 
(a)
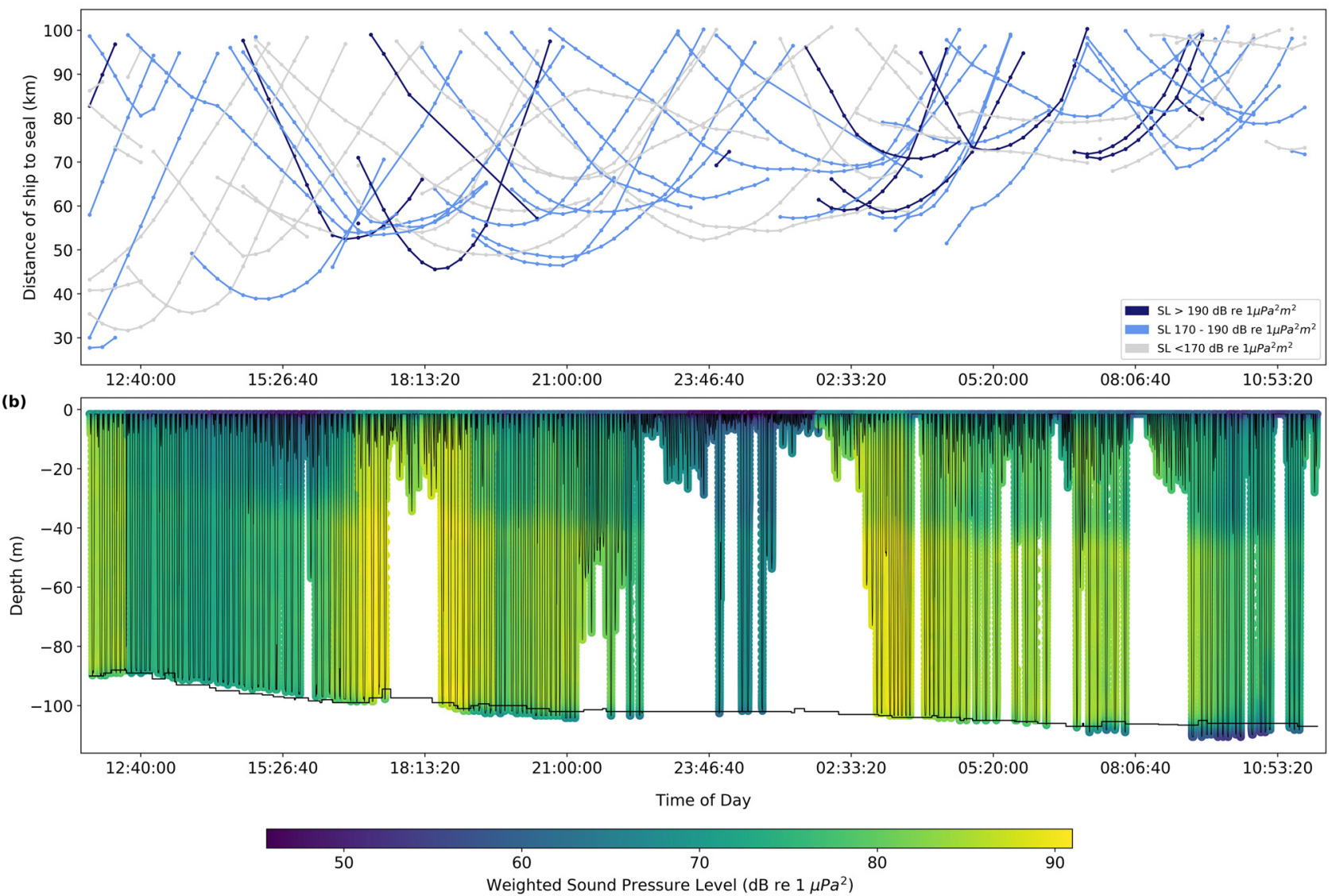

FIG. 5. (Color online) Distance between the seal and each ship (a) and the weighted received SPLs along the dive track of Seal hg29-11-10 in $24 \mathrm{~h}$ in the Celtic Sea (b). The source level of each ship is classified to show the loudest ships. The noise levels are a reflection of the number of ships, distance between seal and ships, and the source level of each ship. The total number of ships in each source level category was 13,36 , and 35 for $>190,170-190,<170 \mathrm{~dB}$ re $1 \mu \mathrm{Pa}^{2} \mathrm{~m}^{2}$, respectively. Time of day starts at 21 st June 2011 at 11:40:00. Black horizontal line indicates bathymetry. Black vertical lines indicate seal dives. Values were weighted as proposed by Southall et al. (2019). Dives below the bathymetry arise from bathymetry referenced to mean seal level, the seal diving throughout the tidal cycle, and location error.

$S E L_{w}$ above effective quiet ranged from 141 to $169 \mathrm{~dB}$ re 1 $\mu \mathrm{Pa}^{2} \mathrm{~s}$ with a median value of $154 \mathrm{~dB}$ re $1 \mu \mathrm{Pa}^{2} \mathrm{~s}$ although, for the majority of days, 68 of 86 , the 24-h $S E L_{w}$ above effective quiet was zero (Table III). Similarly, when values were weighted using the updated function by Southall et al. (2019), there were no instances where $S P L_{w}$ was greater than or equal to the value of effective quiet $(124 \mathrm{~dB}$ re 1 $\left.\mu \mathrm{Pa}^{2}\right)$ in any $24 \mathrm{~h}$ period. The estimated values did not exceed the threshold of 183 or $181 \mathrm{~dB}$ re $1 \mu \mathrm{Pa}^{2}$ s for the onset of TTS when weighted using functions by Southall et al. (2007) and Southall et al. (2019), respectively. The inter-quartile range of predicted 24-h $S E L_{w}$ values given estimated uncertainty in model predictions was between 2 and $6 \mathrm{~dB}$ for all seals (see Supplemental Material ${ }^{1}$ ).

\section{DISCUSSION}

This study presented predictions of the 24-h weighted sound exposure levels for grey seals given the threedimensional at-sea behaviour of individual seals. For pups

TABLE II. The structure of the maximal model with all explanatory variables and each model tested during model selection for the response variable 15 minute weighted sound exposure level.

\begin{tabular}{lccc}
\hline \hline Model & $d f$ & $R^{2}$ (adj) & AIC \\
\hline A: Full $^{\mathrm{a}}$ & 15 & 0.66 & -1242 \\
B: Full - Location $^{\mathrm{b}}$ & 14 & 0.64 & -1248 \\
C: B-NUM & 12 & 0.63 & -1250 \\
D: C-CPA & 10 & 0.61 & -1188 \\
\hline \hline
\end{tabular}

${ }^{\mathrm{a}} \log \left(15 S E L_{w}\right) \sim t i(S L)+t i($ num $)+t i(C P A)+t i(C P A, N U M, S L)+$ location $+(1 \mid$ seal $)+$ corSpher $(1 \mid$ seal $\left.)\right)$.

${ }^{\mathrm{b}} \log \left(15 S E L_{w}\right) \sim t i(S L)+t i($ num $)+t i(C P A)+t i(C P A, N U M, S L)+(1 \mid$ seal $)+$ corSpher $(1 \mid$ seal $\left.)\right)$.

${ }^{\mathrm{c}} \log \left(15 S E L_{w}\right) \sim t i(S L)+t i(C P A)+t i(C P A, N U M, S L)+(1 \mid$ seal $)+$ corSpher $(1 \mid$ seal $\left.)\right)$.

${ }^{\mathrm{d}} \log \left(15 S E L_{w}\right) \sim t i(S L)+t i(C P A, N U M, S L)+(1 \mid$ seal $)+\operatorname{corSpher}(1 \mid$ seal $\left.)\right)$. 

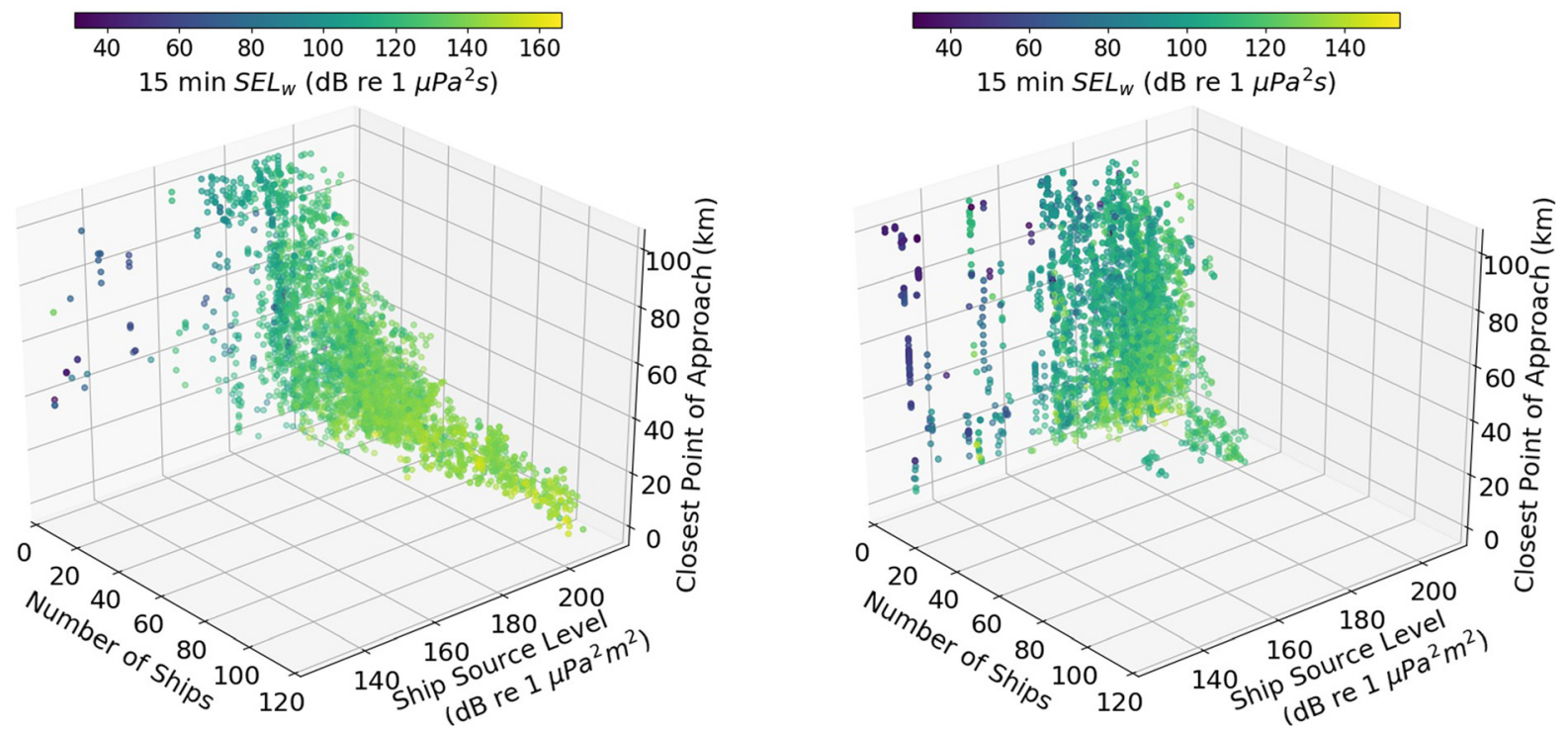

FIG. 6. (Color online) The weighted sound exposure level $S E L_{w}$ in 15 min given the number of ships, the CPA for a single ship, and the maximum ship source level in that 15 min period in the English Channel (left) and the Celtic Sea (right). Note different scales. The 15 -min $S E L_{w}$ were weighted using frequency weighting function for underwater pinnipeds proposed by Southall et al. (2007). The Celtic Sea has fewer of the high noise scenario data points with high source levels, a close approach, and high ship numbers.

primarily located in the Celtic Sea, median 24-h $S E L_{w}$ was $143 \mathrm{~dB}$ re $1 \mu \mathrm{Pa}^{2} \mathrm{~s}$, and for adults primarily located in the English Channel, median 24-h SEL $L_{w}$ was $159 \mathrm{~dB}$ re $1 \mu \mathrm{Pa}^{2} \mathrm{~S}$ (using the Southall et al., 2007 frequency weighting function). It is not possible to give direct comparisons between the two areas or between the adults and pups because data were only available for pups in the Celtic Sea region and adults in the English Channel region confounding any possible comparative analysis. However, given the results presented here, it is reasonable to assume that differences in shipping activity are a driver of differential noise exposure in the two groups. Merchant et al. (2016) highlighted that $125 \mathrm{~Hz}$ octave band noise in the south-eastern Celtic Sea was quieter than Falmouth Bay in the English Channel, and noted it as one of the quietest regions compared to locations in the North Sea. The mean 24-h $S E L_{w}$ recorded using a hydrophone in Falmouth Bay and weighted using the Southall et al. (2007) m-weighting curve for pinnipeds was $156 \pm 19.1 \mathrm{~dB}$ re $1 \mu \mathrm{Pa}^{2} \mathrm{~s}$, a remarkably similar match to average exposure for seals in the English Channel (Merchant et al., 2012). The seals occupy water south-west of Falmouth Bay in busier and, therefore, noisier waters, but their occupation of these waters is temporary because they are transiting through the area unlike the stationary hydrophone in Falmouth Bay. The results are also between 20 and $36 \mathrm{~dB}$ lower than 24-h $S E L_{w}$ values reported for harbour seals in the Moray Firth (Jones et al., 2017). This disparity could arise from differences in shipping traffic but also the propagation model used, the two-dimensional modelling approach, and the wider frequency range $(12.5 \mathrm{~Hz}-20 \mathrm{kHz})$ studied by Jones et al. (2017). In addition, Jones et al. (2017) studied harbour seals which do not travel as far from haul-out sites (Thompson et al., 1996), and, therefore, may be more resident in areas of high shipping traffic. However, the results highlight spatial variation in noise patterns and shipping traffic in different regions. It provides evidence that regional variations must be considered carefully in underwater noise management plans.

$S P L_{w}$ values ranged from 0 to $140 \mathrm{~dB}$ re $1 \mu \mathrm{Pa}^{2}$ and median maximum $S P L_{w}$ in a day was 115 and $99 \mathrm{~dB}$ re 1 $\mu \mathrm{Pa}^{2}$ when weighted as proposed by Southall et al. (2007) and Southall et al. (2019), respectively. Ambient sound levels (ISO, 2017) absent of shipping noise in the region were not available as part of this study, but measurements by Merchant et al. (2016) at one location in the Celtic Sea suggested median ambient sound levels to be $83.3 \mathrm{~dB}$ re $1 \mu \mathrm{Pa}^{2}$ at $125 \mathrm{~Hz}$. In the English Channel, recordings from Falmouth Harbour measured broadband $(0.01-1 \mathrm{kHz})$ SPLs between 86.1 and $148.6 \mathrm{~dB}$ re $1 \mu \mathrm{Pa}^{2}$ and the minimum recorded level (representative of ambient sound in the absence of shipping) was $96.2 \mathrm{~dB}$ re $1 \mu \mathrm{Pa}^{2}$ (Merchant et al., 2012). These values suggest that the seals were exposed to sound from shipping above that which could be considered ambient sound levels in both the Celtic Sea and English Channel. However, the estimated level of effective quiet for grey seals is $124 \mathrm{~dB}$ re $1 \mu \mathrm{Pa}^{2}$ and the $S P L_{w}$ values remained below this for many of the seals.

The $S E L_{w}$ in 15 min was closely related to the number of ships, the CPA of any ship, and the source level of the loudest ships in that $15 \mathrm{~min}$. For example, ships with high source levels over $50 \mathrm{~km}$ from the seal still resulted in received $S P L_{w}$ greater than $100 \mathrm{~dB}$ re $1 \mu \mathrm{Pa}^{2}$ for a seal in the Celtic Sea (Fig. 5). These exposures may be indistinguishable from ambient sound for seals, but they will raise the overall ambient sound levels and may be of concern for issues such as call masking and chronic stress related to sustained exposure (Rolland et al., 2012). Ship noise exposure detectable above ambient sound levels will be most relevant 


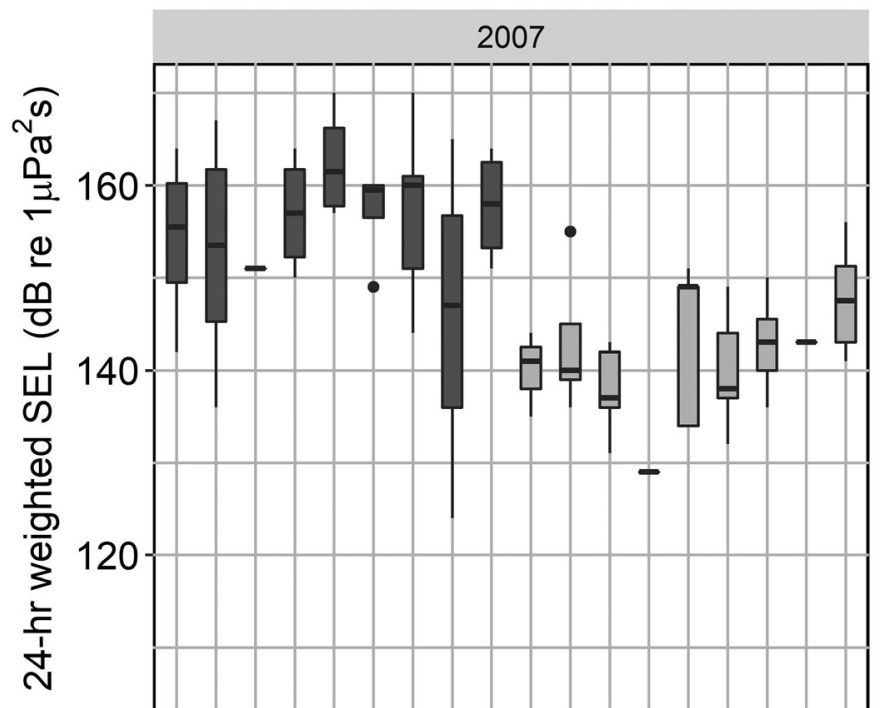

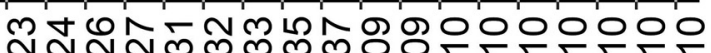

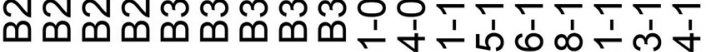

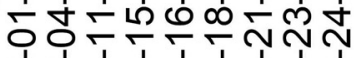

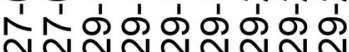

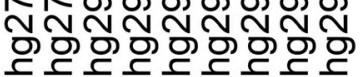

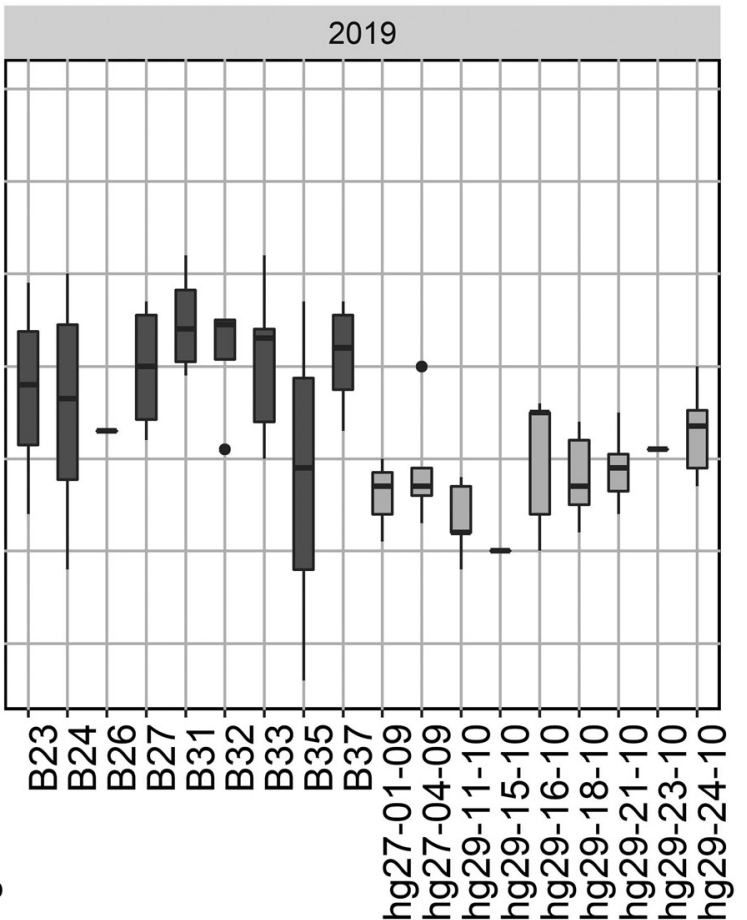

Seal

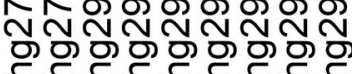

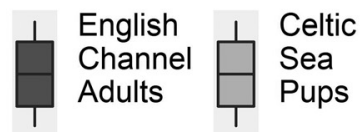

FIG. 7. The 24-h weighted sound exposure levels for adult seals in the English Channel and pups in the Celtic Sea. The values were weighted using the frequency weighting function for underwater pinnipeds from Southall et al. (2007) (left panel) or underwater phocid pinnipeds from Southall et al. (2019) (right panel). A total of 86 days were processed for nine adult seals and nine seal pups.

TABLE III. The 24-hr weighted sound exposure levels $\left(S E L_{w}\right)$ including only $S P L_{w}$ greater than effective quiet set at a value of $124 \mathrm{~dB}$ re $1 \mu \mathrm{Pa}^{2}$. The number of minutes $S P L_{w}$ was greater than effective quiet and the maximum $S P L_{w}$ predicted in 24-h. Values were weighted as proposed by Southall et al. (2007). When weighted using function for phocid pinnipeds proposed by Southall et al. (2019), there were no $S P L_{w}$ above effective quiet.

\begin{tabular}{lccc}
\hline \hline & & $\begin{array}{c}\text { 24-hr SELw above } \\
\text { effective quiet } \\
\text { Seal }\end{array}$ & $\begin{array}{c}\text { Minutes above } \\
(\mathrm{dB} \text { effective quiet }\end{array}$ \\
\hline B31 $\left.1 \mu \mathrm{Pa}^{2}\right)$ & 162 & 34 \\
B31 & 133 & 168 & 176 \\
B32 & 134 & 152 & 9 \\
B32 & 126 & 142 & 1 \\
B35 & 124 & 159 & 24 \\
B37 & 130 & 158 & 38 \\
B32 & 126 & 153 & 10 \\
B27 & 126 & 162 & 52 \\
B23 & 131 & 154 & 12 \\
B24 & 126 & 164 & 107 \\
B24 & 130 & 141 & 0.8 \\
B31 & 125 & 153 & 12 \\
B33 & 126 & 169 & 90 \\
B33 & 140 & 156 & 13 \\
B33 & 128 & 147 & 3 \\
B33 & 125 & 168 & 10 \\
B37 & 138 & 153 & 90 \\
h929-24-10 & 126 & 154 & 12 \\
\hline \hline
\end{tabular}

for determining auditory damage and possible behavioural responses to noise, and these generally arose from ships closer to the seal and with higher source levels. However, the results demonstrated the ability of high numbers of loud ships far away from the seal to generate high noise exposure levels at the seal's location. This suggests that when assessing the impacts of shipping noise, the area over which ships are included in calculations of noise levels should be sufficiently wide to capture such exposure and not just focus on the first few kilometres from the seal (Mikkelsen et al., 2019).

In addition to shipping traffic alone, the difference in behaviour between English Channel adults and Celtic Sea pups as a result of age or location specific factors such as bathymetry may also be mediating noise exposure in the two groups. Figure 1 shows that the seals in the Celtic Sea were mainly located to the north of the region where shipping density is lower. English Channel seals cross an area of very high intensity shipping. However, compared to their whole track they tend to make this crossing only once or twice, and visual inspection of the track suggests they are undertaking directed travel through the area. The majority of their time was spent around the islands within the Iroise Marine Park. The noise levels in this area are unknown but are likely to be different as a result of lower numbers of large ships. Huon et al. (2015) studied 19 seals, nine of 
which are included here, and found that individuals spent $67 \%$ of their time within the Marine Park. Harbour seals in the Moray Firth, which experience much higher cumulative noise levels, also tend to remain close to the coast. However, they are resident within the zones of higher intensity shipping (Jones et al., 2017). This could account for their higher exposure.

Recommendations for appropriate frequency weighting functions and TTS onset thresholds have been systematically updated with the availability of new audiometric studies and approaches (National Marine Fisheries Service, 2018; Southall et al., 2007; Southall et al., 2019). Specifically, Southall et al. (2019) present separate frequency weighting functions and TTS onset thresholds for otariid and phocid pinnipeds. When compared to the underwater pinniped frequency weighting function proposed by Southall et al. (2007), this updated function for phocid pinnipeds underwater shows reduced hearing sensitivity at low frequencies. This is particularly true between 10 and $1000 \mathrm{~Hz}$, the dominant frequencies emitted by ships. This accounts for the 9-18 dB difference between 24-h $S E L_{w}$ using the two functions. However, Southall et al. (2019) recognise limits on high frequency hearing exceeded $60 \mathrm{kHz}$ for many phocid species. Therefore, it may be necessary to consider a wider frequency range when predicting the exposure of phocid pinnipeds to shipping noise. Southall et al. (2007) took a necessarily cautious approach due to the limited available data. This approach may still be useful if a regulatory scenario also requires a precautionary approach, and when comparing predicted exposure to historical measurements that have been subsequently frequency weighted.

Southall et al. (2019) proposed that, given the best available data, phocid seals will experience TTS for underwater non-impulsive sounds such as shipping noise when weighted sound exposure levels exceed $181 \mathrm{~dB}$ re $1 \mu \mathrm{Pa}^{2}$ s. In older recommendations, this threshold was $183 \mathrm{~dB}$ re 1 $\mu \mathrm{Pa}^{2}$ s (Southall et al., 2007). The exposure of seals above effective quiet in this study did not exceed these threshold values when weighted using the appropriate comparable frequency weighting function. For the most precautionary approach, using Southall et al. (2007) frequency weighting functions, eight adults and one pup for a total of 18 days experienced $S P L_{w}$ greater than the values of effective quiet. The 24-h $S E L_{w}$ above effective quiet range from 141 to $169 \mathrm{~dB}$ re $1 \mu \mathrm{Pa}^{2}$ s and as such are between 14 and $42 \mathrm{~dB}$ below the threshold level for TTS. Auditory weighting functions and TTS onset thresholds have been derived from direct measurements of hearing thresholds, consideration of auditory anatomy, and data on sound production capabilities (Southall et al., 2019). However, these studies often utilise only one or two individuals (Southall et al., 2019). Furthermore, there is very limited auditory data specifically studying the underwater hearing of adult grey seals or pups (Finneran, 2015; Southall et al., 2019). Pups may be more sensitive to noise but future work is necessary to explore the sensitivity of animals in this vulnerable juvenile stage.
Temporary threshold shift is determined by exposure frequency, duration, SPL, temporal pattern of noise, and available recovery time (Finneran and Branstetter, 2013; Finneran, 2015). Kastak and Schusterman (1999) found average threshold shift of $4.8 \mathrm{~dB}$ given exposure for $20 \mathrm{~min}$ at $100 \mathrm{~Hz}$ to SPLs ranging from 133 to $156 \mathrm{~dB}$ re $1 \mu \mathrm{Pa}^{2}$. These conditions were met three times in this study. Many studies of TTS growth and recovery in phocid seals examined frequencies higher $(2.5-4 \mathrm{kHz})$ than the peak shipping noise used in this study $(10-1000 \mathrm{~Hz})$ and higher SPL values than seals were exposed to in these calculations. Kastelein et al. (2012) tested the hearing of two harbour seals using octave band noise at a centre frequency of $4 \mathrm{kHz}$. They showed maximum TTS of $10 \mathrm{~dB} 1-4 \mathrm{~min}$ after a $120 \mathrm{~min}$ exposure to $148 \mathrm{~dB}$ re $1 \mu \mathrm{Pa}^{2}$. TTS began to occur at SPLs of $136 \mathrm{~dB}$ for $60 \mathrm{~min}$. This suggests any one of the properties (exposure frequency, duration, etc.) determining TTS should be closely monitored for changes that may result in exposures great enough to induce TTS. In addition, mitigation measures to address any detected increase in underwater noise from shipping should consider the impact of SPLs but also exposure duration and frequency, given their ability to influence levels of TTS experienced by the seals (Finneran and Branstetter, 2013; Finneran, 2015; Joy et al., 2019).

Twenty-four hour sound exposure levels are often considered for regulatory assessments because the metric considers the duration of exposure as well as SPL and frequency (Finneran and Branstetter, 2013). The standard duration of exposure for non-impulsive sounds such as shipping noise has been $24 \mathrm{~h}$ (National Marine Fisheries Service, 2018; Southall et al., 2007). However, it is recognised that this is an arbitrary value (Southall et al., 2019). If a species shows high site fidelity at a high exposure zone they may be exposed for much longer than $24 \mathrm{~h}$. Alternatively, individuals may move in and out of high exposure zones. Particularly, for sources such as ships that are highly mobile, peaks in noise may be quite short and an individual may have periods where shipping noise could be zero. The development of a more ecologically relevant value is key for future policy and management of noise (National Marine Fisheries Service, 2018). Seals spend time at-sea between periods of haul-out; therefore, the duration over which seals are potentially exposed to underwater noise varies and supports the assertion that the accumulation period appropriate for a specific species or noise source will vary. The mean length of exposures above effective quiet in $24 \mathrm{~h}$ was $38.47 \mathrm{~min}$ but some of the Celtic Sea pups spent greater than 2 months at sea (Carter et al., 2017). The 24-h $S E L_{w}$ metric assumes the "equal energy" hypothesis, whereby exposures of equal energy are assumed to result in the same amounts of threshold shift regardless of how the exposure is distributed in time (Finneran and Branstetter, 2013). It is known that the equal-energy approach overestimates intermittent exposures because it does not consider the recovery that can occur from TTS between the noise exposures within the total accumulation period (Finneran 
and Branstetter, 2013). Hence, for seals, a continuous accumulation period of $24 \mathrm{~h}$, as used in this study, may result in higher levels of TTS than if periods of haul-out and recovery are included.

In addition to possible auditory damage, behavioural responses and physiological responses have been recorded for a number of marine species to shipping noise (Blair et al., 2016; Celi et al., 2015; Rolland et al., 2012; Williams et al., 2002). Seals have shown behavioural reactions such as entering the water, decrease in resting behaviour, and increase in alert behaviour at the sight of approaching boats and boat noise playbacks when hauled out (Jansen et al., 2015; Tripovich et al., 2012). There is only limited anecdotal evidence of changes in the at-sea behaviour of seals in response to shipping noise (Mikkelsen et al., 2019). As such, acceptable exposure levels with respect to behavioural changes are unknown, and crucially, if there is a behavioural response, what level of behavioural response is harmful for individual survival and population stability (McHuron et al., 2017). The results show that seals are exposed to shipping noise and this is likely to be above ambient sound levels generated by other sound sources. Therefore, further assessment of the behavioural responses of seals to this noise is warranted. This may be especially true of grey seal pups that are potentially naive to underwater anthropogenic noise when they leave breeding colonies for the first time. To avoid starvation, they must rapidly develop at-sea movement and foraging behaviour without parental guidance, making them vulnerable to disturbance (Carter et al., 2017). Furthermore, the prolonged immaturity of grey seal pups (5year-old females; 10-year-old males) means that increased pup mortality will not immediately manifest itself in observable population dynamics (Harwood and Prime, 1978).

Exposure levels and at-sea spatial usage are key parameters in understanding the spatial risk for marine animals of exposure to shipping noise and are required to set effective management targets (Erbe et al., 2014). The results can contribute to the estimation of noise budgets and assessments of soundscapes that will help close the gap to establishing quantitative noise level targets that regulators can enforce. As described by Merchant et al. (2017), population density and noise exposure can be combined to provide risk maps. This is a similar approach as that implemented by Erbe et al. (2012a). However, the majority of the distribution and noise based information is related to two-dimensional maps. In contrast, the results presented assess the noise exposure for seals using their three-dimensional dive track and adds the new dimension of depth to risk based assessment of noise levels for management goals. The results suggest that when seals are located at the surface or at the sea floor, they may experience lower noise levels due to surface and bottom losses. This observation highlights the potential importance of considering three-dimensional space use by marine animals when calculating exposure, especially those that utilise the complete water column (Chen et al., 2017).

The predictions presented in this study are subject to a number of limitations and uncertainties, including the source level estimates (Simard et al., 2016), missing ships and incomplete transects in the AIS data (Hermannsen et al., 2019), and uncertainty in the environmental input data. The inter-quartile range of predicted 24-h $S E L_{w}$ values given estimated uncertainty in model predictions was between 2 and $6 \mathrm{~dB}$ for all seals (see Supplemental Material ${ }^{1}$ ). The resulting noise exposure estimates should be viewed in this context and in combination with noise estimates for other noise sources. However, this study used a sophisticated acoustic propagation model that has been benchmarked and compared to experimental data (Davis et al., 1982; Hanna and Rost, 1981). RAMSurf considers detailed representations of environmental properties that are particularly important in shallow water propagation scenarios. It has been highlighted that in such scenarios, simple spreading laws can result in significant errors (Farcas et al., 2016; Robinson et al., 2014). The uncertainties associated with the simple spreading model could account for some of the differences seen in ship noise exposure between the Moray Firth and the region of south-west UK considered here. Validation of the Jones et al. (2017) model alone suggests that median absolute error in the model was 9.75 (2.11-24.51) dB (Jones et al., 2019).

In summary, at-sea, three-dimensional exposure of grey seals to shipping noise ranged from 124 to $170 \mathrm{~dB}$ re 1 $\mu \mathrm{Pa}^{2} \mathrm{~s}$ in 24-h when weighted using the underwater frequency weighting function for pinnipeds proposed by Southall et al. (2007). However, only nine seals were exposed to weighted SPLs greater than the estimated value of effective quiet for phocid seals, and 24-h $S E L_{w}$ based on exposures above effective quiet ranged from 141 to $169 \mathrm{~dB}$ re $1 \mu \mathrm{Pa}^{2}$ s. In contrast, when values are weighted using the updated frequency weighting function for underwater phocid pinnipeds, 24-h SEL $L_{w}$ was between 106 and $152 \mathrm{~dB}$ re 1 $\mu \mathrm{Pa}^{2} \mathrm{~s}$ and $S P L_{w}$ did not exceed effective quiet on any occasion. The exposure of seals to shipping noise did not exceed best evidence thresholds for TTS. The exposure of the seals was mediated by the number of ships, CPA of these ships, maximum ship source level, and the at-sea behaviour of the seals. This study presents vital data on the exposure of grey seals and the influence of shipping traffic on this exposure. This is central to our understanding of the risks posed by shipping noise and can inform marine spatial planning in the future. A major obstacle to concrete policy commitments on shipping noise is a lack of understanding of marine noise budgets, which characterise the contribution of different noise sources to the overall underwater soundscape (Merchant et al., 2017). Exposure values reported here contribute to such noise budgets by representing the total contribution of shipping to the seals' soundscape.

\section{ACKNOWLEDGMENTS}

This paper was presented at the Fifth International Meeting on The Effects of Noise on Aquatic Life held in Den Haag, the Netherlands, July 2019. We are grateful to Natural Resources Wales (NRW) and the Royal Society for the Protection of Birds (RSPB) for permission to work on 
Welsh seal colonies. In Wales, tags and their deployments were funded by the Welsh Assembly Government (Welsh colonies; Project No. JER3688). Seal tracking in France was funded by the Parc naturel marin d'Iroise (PNMI) and the Regional Council of Poitou-Charentes (France), and we acknowledge SMRU, the PNMI, the Office National de la Chasse et de la Faune Sauvage (ONCFS), the Obervatoire PELAGIS, the Zoo de La Fleche, and Oceanopolis for their help in the field. AIS data was generously provided by Ian McConnell and contributors to shipais.com. We thank Dr. Gordon Hastie for useful discussions on the manuscript and Clint Blight for VORF data processing. L.E.T. was supported by a Plymouth University Research Studentship. D.J.F.R. and D.T. are supported by National Capability funding from NERC to SMRU (Grant No. SMRU1001). M.I.D.C. is supported by the Department for Business, Energy and Industrial Strategy.

${ }^{1}$ See supplemental materials at https://doi.org/10.1121/10.0001727 for details of the acoustic model parameters, sensitivity analysis, estimation of uncertainty, and model validation plots.

Adams, R., Iliffe, J., Ziebart, M., Turner, J., and Oliveira, J. F. (2006). "Joining up land and sea: UKHO/UCL vertical offshore reference frame," Hydro Int. 10(10), 7-9.

Asselin, S., Hammill, M. O., and Barrette, C. (1993). "Underwater vocalizations of ice breeding grey seals," Can. J. Zool. 71(11), 2211-2219.

Bagočius, D. (2014). "Potential masking of the Baltic Grey Seal vocalisations by underwater shipping noise in the Lithuanian area of the Baltic Sea," Environ. Res. Eng. Manage. 4(70), 66-72.

Blair, H. B., Merchant, N. D., Friedlaender, A. S., Wiley, D. N., and Parks, S. E. (2016). "Evidence for ship noise impacts on humpback whale foraging behaviour," Biol. Lett. 12(8), 419-427.

Breeding, J., Pflug, L. A., Bradley, M., Walrod, M. H., and McBride, W. (1996). "Research Ambient Noise Directionality (RANDI) 3.1 physics description," Naval Research Laboratory, Washington, D.C.

Brooker, A., Humphrey, V., Mumm, H., Jansen, E., and de Jong, C. (2015). "Development of improved noise models for radiated noise/source level using database," Suppression of Underwater Noise Induced by Cavitation Project. SONIC-SOTON-DEL-D2.4-V1.0.

Carter, M. I. D., Bennett, K. A., Embling, C. B., Hosegood, P. J., and Russell, D. J. F. (2016). "Navigating uncertain waters: A critical review of inferring foraging behaviour from location and dive data in pinnipeds," Move. Ecol. 4(1), 25.

Carter, M. I. D., Russell, D. J. F., Embling, C. B., Blight, C. J., Thompson, D., Hosegood, P. J., and Bennett, K. A. (2017). "Intrinsic and extrinsic factors drive ontogeny of early-life at-sea behaviour in a marine top predator," Sci. Rep. 7, 15505.

Celi, M., Filiciotto, F., Vazzana, M., Arizza, V., Maccarrone, V., Ceraulo, M., Mazzola, S., and Buscaino, G. (2015). "Shipping noise affecting immune responses of European spiny lobster (Palinurus elephas)," Can. J. Zool. 93(2), 113-121.

Chen, F., Shapiro, G., Bennett, K., Ingram, S., Thompson, D., Vincent, C., Russell, D., and Embling, C. (2017). "Shipping noise in a dynamic sea: A case study of grey seals in the Celtic Sea," Mar. Poll. Bull. 114(1), 372-383.

Chion, C., Lagrois, D., and Dupras, J. (2019). "A meta-analysis to understand the variability in reported source levels of noise radiated by ships from opportunistic studies," Front. Mar. Sci. 6, 714.

Collins, M. D. (1993). "A split-step Padé solution for the parabolic equation method,” J. Acoust. Soc. Am. 93(4), 1736-1742.

Davis, J. A., White, D., and Cavanagh, R. C. (1982). "NORDA parabolic equation workshop," Report No. TN-143, NSTL Station, MS.

Dujon, A. M., Lindstrom, R. T., and Hays, G. C. (2014). "The accuracy of Fastloc-GPS locations and implications for animal tracking," Methods Ecol. Evol. 5(11), 1162-1169.
Dyndo, M., Wiśniewska, D. M., Rojano-Doñate, L., and Madsen, P. T. (2015). "Harbour porpoises react to low levels of high frequency vessel noise," Sci. Rep. 5, 11083.

EMODnet Bathymetry Consortium (2016). "EMODnet Digital Bathymetry (DTM 2016)," http://doi.org/10.12770/c7b53704-999d-4721-b1a304ec60c87238 (Last viewed January 16, 2017).

Erbe, C., MacGillivray, A., and Williams, R. (2012a). "Mapping cumulative noise from shipping to inform marine spatial planning," J. Acoust. Soc. Am. 132(5), EL423.

Erbe, C., MacGillivray, A., and Williams, R. (2012b). "Mapping ocean noise: Modelling cumulative acoustic energy from shipping in British Columbia to inform marine spatial planning," WWF Canada and Curtin University, Perth, Australia.

Erbe, C., Marley, S. A., Schoeman, R. P., Smith, J. N., Trigg, L. E., and Embling, C. B. (2019). "The effects of ship noise on marine mammalsA review," Front. Mar. Sci. 6, 606.

Erbe, C., Williams, R., Sandilands, D., and Ashe, E. (2014). "Identifying modeled ship noise hotspots for marine mammals of Canada's Pacific region," PLoS One 9(3), e89820.

Etter, P. (2013). Underwater Acoustic Modeling and Simulation, 4th ed. (CRC Press, Boca Raton, FL).

European Commission (2008). "Directive 2008/56/EC of the European Parliament and of the Council of 17 June 2008 establishing a framework for community action in the field of marine environmental policy (Marine Strategy Framework Directive)," European Commission, Brussels, Belgium.

European Commission (2010). "2010/477/EU: Commission Decision of 1 September 2010 on criteria and methodological standards on good environmental status of marine waters (notified under document C(2010) 5956)," European Commission, Brussels, Belgium.

European Commission (2016). "EMODnet geology project," http://www.emodnet-geology.eu (Last viewed July 20, 2016).

European Commission (2017). "Commission Decision (EU) 2017/848 of 17 May 2017 laying down criteria and methodological standards on good environmental status of marine waters and specifications and standardised methods for monitoring and assessment, and repealing Decision 2010/ 477/EU," European Commission, Brussels, Belgium.

Farcas, A., Thompson, P. M., and Merchant, N. D. (2016). "Underwater noise modelling for environmental impact assessment," Environ. Impact Assess. Rev. 57, 114-122.

Finneran, J. J. (2015). "Noise-induced hearing loss in marine mammals: A review of temporary threshold shift studies from 1996 to 2015," J. Acoust. Soc. Am. 138(3), 1702-1726.

Finneran, J., and Branstetter, B. (2013). "Effects of noise on sound perception in marine mammals," in Animal Communication and Noise. Animal Signals and Communication, edited by H. Brumm (Springer, Berlin), Vol. 2, pp. 273-308.

Frisk, G. V. (2012). "Noiseonomics: The relationship between ambient noise levels in the sea and global economic trends," Sci. Rep. 2, 437.

Hamilton, E. L. (1980). "Geoacoustic modeling of the sea floor," J. Acoust. Soc. Am. 68(5), 1313-1340.

Hanna, J. S., and Rost, P. V. (1981). "Parabolic equation calculations versus North Pacific measurement data," J. Acoust. Soc. Am. 70(2), 504-515.

Harrison, C. H., and Harrison, J. A. (1995). "A simple relationship between frequency and range averages for broadband sonar," J. Acoust. Soc. Am. 97(2), 1314-1317.

Harwood, J., and Prime, J. (1978). "Some factors affecting the size of British grey seal populations,” J. Appl. Ecol. 15, 401-411.

Hastie, G. D., Russell, D. J. F., Lepper, P., Elliott, J., Wilson, B., Benjamins, S., and Thompson, D. (2018). "Harbour seals avoid tidal turbine noise: Implications for collision risk," J. Appl. Ecol. 55(2), 684-693.

Hatch, L. T., Clark, C. W., Van Parijs, S. M., Frankel, A. S., and Ponirakis, D. W. (2012). "Quantifying loss of acoustic communication space for right whales in and around a U.S. National Marine Sanctuary," Coserv. Biol. 26(6), 983-994.

Hayes, S. A., Costa, D. P., Harvey, J. T., and Boeuf, B. J. (2004). "Aquatic mating strategies of the male pacific harbor seal (Phoca vitulina richardii): Are males defending the hotspot?," Mar. Mam. Sci. 20(3), 639-656.

Hermannsen, L., Mikkelsen, L., Tougaard, J., Beedholm, K., Johnson, M., and Madsen, P. T. (2019). "Recreational vessels without automatic identification system (AIS) dominate anthropogenic noise contributions to a shallow water soundscape," Sci. Rep. 9, 15477. 
Hoffmann, J., and Kumar, S. (2010). "Globalisation-The maritime nexus," in The Handbook of Maritime Economics and Business, edited by C. T. Grammenos (Informa Law from Routledge, London), 2nd ed., pp. 35-64.

Huon, M., Jones, E. L., Matthiopoulos, J., McConnell, B., Caurant, F., and Vincent, C. (2015). "Habitat selection of gray seals (Halichoerus grypus) in a marine protected area in France," J. Wildlife Manage. 79(7), 1091-1100.

ISO (2017). 18405:2017, Underwater Acoustics-Terminology (International Organisation for Standardisation, Geneva, Switzerland).

ISO (2019). 17208-2:2019, Underwater Acoustics-Quantities and Procedures for Description and Measurement of Underwater Sound From Ships-Part 2: Determination of Source Levels From Deep Water Measurements (International Organisation for Standardisation, Geneva, Switzerland).

Jansen, J. K., Brady, G. M., Ver Hoef, J. M., Boveng, P. L., Suydam, R., and Clark, C. (2015). "Spatially estimating disturbance of harbor seals (Phoca vitulina)," PLoS One 10(7), e0129798.

Jansen, E., and de Jong, C. (2017). "Experimental assessment of underwater acoustic source levels of different ship types," IEEE J. Oceanic Eng. 42(2), 439-448.

Jensen, F., Bejder, L., Wahlberg, M., Aguilar Soto, N., Johnson, M., and Madsen, P. T. (2009). "Vessel noise effects on delphinid communication," Mar. Ecol. Prog. Ser. 395, 161-175.

Jessopp, M., Cronin, M., and Hart, T. (2013). "Habitat-mediated dive behavior in free-ranging grey seals.," PLoS ONE 8(5), e63720.

Jones, E. L., Hastie, G. D., Smout, S., Onoufriou, J., Merchant, N. D., Brookes, K. L., and Thompson, D. (2017). "Seals and shipping: Quantifying population risk and individual exposure to vessel noise," J. Appl. Ecol. 54, 1930-1940.

Jones, E. L., Hastie, G. D., Smout, S., Onoufriou, J., Merchant, N. D., Brookes, K. L., and Thompson, D. (2019). "Corrigendum," J. Appl. Ecol. 56(3), 792.

Joy, R., Tollit, D., Wood, J., MacGillivray, A., Li, Z., Trounce, K., and Robinson, O. (2019). "Potential benefits of vessel slowdowns on endangered southern resident killer whales," Front. Mar. Sci. 6, 344.

Karasalo, I., Östberg, M., Sigray, P., Jalkanen, J.-P., Johansson, L., Liefvendahl, M., and Bensow, R. (2017). "Estimates of source spectra of ships from long term recordings in the Baltic Sea," Front. Mar. Sci. 4, 164.

Kastak, D., and Schusterman, R. (1999). "In-air and underwater hearing sensitivity of a northern elephant seal (Mirounga angustirostris)," Can. J. Zool. 77(11), 1751-1758.

Kastelein, R. A., Gransier, R., Hoek, L., Macleod, A., and Terhune, J. M. (2012). "Hearing threshold shifts and recovery in harbor seals (Phoca vitulina) after octave-band noise exposure at $4 \mathrm{kHz}$," J. Acoust. Soc. Am. 132(4), 2745-2761.

Kuhn, C., Tremblay, Y., Ream, R., and Gelatt, T. (2010). "Coupling GPS tracking with dive behavior to examine the relationship between foraging strategy and fine-scale movements of northern fur seals," Endang. Spec. Res. 12(2), 125-139.

Long, D. (2006). "BGS detailed explanation of seabed sediment modified folk classification," EMODnet, https://webarchive.nationalarchives.gov.uk/ 20090606235257/http://www.searchmesh.net/PDF/GMHM3_Detailed_ explanation_of_seabed_sediment_classification.pdf (Last viewed 19 May 2020).

Mackenzie, K. V. (1981). "Nine term equation for sound speed in the oceans," J. Acoust. Soc. Am. 70(3), 807-812.

Marine Management Organisation (2014). "Mapping UK shipping density and routes technical annex. MMO Project No: 1066," MMO Project No: 1066, MMO, Newcastle, UK.

Marine Management Organisation (2015). "Modelled mapping of continuous underwater noise generated by activities. A report produced for the Marine Management Organisation," MMO Project No: 1097, MMO, Newcastle, UK.

Martin, S. B., Morris, C., Bröker, K., and O’Neill, C. (2019). "Sound exposure level as a metric for analyzing and managing underwater soundscapes," J. Acoust. Soc. Am. 146(1), 135-149.

McConnell, B., Fedak, M., Lovell, P., and Hammond, P. (1999). "Movements and foraging areas of grey seals in the North Sea," J. Appl. Ecol. 36(4), 573-590.

McHuron, E. A., Costa, D. P., Schwarz, L., and Mangel, M. (2017). "Statedependent behavioural theory for assessing the fitness consequences of anthropogenic disturbance on capital and income breeders," Methods Ecol. Evol. 8(5), 552-560.

Merchant, N. D. (2019). "Underwater noise abatement: Economic factors and policy options,” Environ. Sci. Policy 92, 116-123.

Merchant, N., Brookes, K., and Faulkner, R. (2016). "Underwater noise levels in UK waters," Sci. Rep. 6, 36942.

Merchant, N. D., Faulkner, R. C., and Martinez, R. (2017). "Marine noise budgets in practice," Conserv. Lett. 11(3), e12420.

Merchant, N. D., Witt, M. J., Blondel, P., Godley, B. J., and Smith, G. H. (2012). "Assessing sound exposure from shipping in coastal waters using a single hydrophone and Automatic Identification System (AIS) data," Mar. Pollut. Bull. 64(7), 1320-1329.

Mikkelsen, L., Johnson, M., Wisniewska, D. M., van Neer, A., Siebert, U., Madsen, P. T., and Teilmann, J. (2019). "Long term sound and movement recording tags to study natural behavior and reaction to ship noise of seals," Ecol. Evol. 9(5), 2588-2601.

National Marine Fisheries Service (2018). "2018 Revision to: Technical guidance for assessing the effects of anthropogenic sound on marine mammal hearing (Version 2.0): Underwater acoustic thresholds of permanent and temporary threshold shifts," http://doi.org/10.7289/V5/TMNMFS-OPR-55.

Peng, Z., Wang, B., and Fan, J. (2018). "Assessment on source levels of merchant ships observed in the East China Sea," Ocean Eng. 156, 179-190.

Photopoulou, T., Fedak, M. A., Thomas, L., and Matthiopoulos, J. (2014). "Spatial variation in maximum dive depth in gray seals in relation to foraging," Mar. Mam. Sci. 30(3), 923-938.

Pingree, R. (1980). "Chapter 13: Physical oceanography of the Celtic Sea and English Channel," in The North-West European Shelf Seas: The Sea Bed and the Sea in Motion II. Physical and Chemical Oceanography, and Physical Resources, Elsevier Oceanography Series (Elsevier, Amsterdam, the Netherlands), Vol. 24, pp. 415-465.

$\mathrm{R}$ Core Team (2019). "R: A language and environment for statistical computing," https://www.r-project.org/ (18 November 2019).

Robinson, S. P., Lepper, P. A., and Hazelwood, R. A. (2014). "Good practice guide for underwater noise measurement," in NPL Good Practice Guide No. 133 (National Physical Laboratory, National Measurement Office, Marine Scotland, The Crown Estate, UK).

Rolland, R. M., Parks, S. E., Hunt, K. E., Castellote, M., Corkeron, P. J., Nowacek, D. P., Wasser, S. K., and Kraus, S. D. (2012). "Evidence that ship noise increases stress in right whales," Proc. R. Soc. B Biol. Sci. 279(1737), 2363-2368.

Ross, D. (1976). Mechanics of Underwater Noise (Pergamon Press, New York).

Russell, D. J., and McConnell, B. (2014). "Seal at-sea distribution, movements and behaviour," Report to the DECC, Sea Mammal Research Unit, St. Andrews, UK.

SCOS (2018). "Scientific advice on matters related to the management of seal populations: 2018," Special Committee on Seals, St. Andrews, UK.

Scrimger, P., and Heitmeyer, R. (1991). "Acoustic source level measurements for a variety of merchant ships,” J. Acoust. Soc. Am. 89, 691.

Shapiro, G., Chen, F., and Thain, R. (2014). "The effect of ocean fronts on acoustic wave propagation in the Celtic Sea," J. Mar. Syst. 139, 217-226.

ShipAIS (2018). "ShipAIS - UK vessel movements and visualisation from AIS data," http://www.shipais.com/ (Last viewed 7 March 2018).

Shom (2015). "MNT Bathymétrique de façade Atlantique (Projet Homonim)" ("Bathymetric DEM of Atlantic Coast (Project Homonim)"), http://dx.doi.org/10.17183/MNT_ATL100m_HOMONIM_WGS84le.

Simard, Y., Roy, N., Gervaise, C., and Giard, S. (2016). "Analysis and modeling of 255 source levels of merchant ships from an acoustic observatory along St. Lawrence Seaway," J. Acoust. Soc. Am. 140(3), 2002-2018.

Simpson, J., and Sharples, J. (2012). Introduction to the Physical and Biological Oceanography of Shelf Seas (Cambridge University Press, Cambridge, UK).

Southall, B., Bowles, A., Ellison, W., Finneran, J., Gentry, R., Greene, C., Kastak, D., Ketten, D., Miller, J., Nachtigall, P., Richardson, W., Thomas, J., and Tyack, P. (2007). "Marine mammal noise exposure criteria: Initial scientific recommendations," Aquatic Mam. 33(4), 411-522.

Southall, B. L., Finneran, J. J., Reichmuth, C., Nachtigall, P. E., Ketten, D. R., Bowles, A. E., Ellison, W. T., Nowacek, D. P., and Tyack, P. L. (2019). "Marine mammal noise exposure criteria: Updated scientific 
recommendations for residual hearing effects," Aquatic Mam. 45(2), 125-232.

Thompson, D. (2012). "Assessment of risk to marine mammals from underwater marine renewable devices in Welsh waters. Annex I: Movements and diving behaviour of juvenile grey seals in areas of high tidal energy," Report for the Welsh Assembly Government, Cardiff, UK.

Thompson, D., Hammond, P. S., Nicholas, K. S., and Fedak, M. A. (1991). "Movements, diving and foraging behaviour of grey seals (Halichoerus grypus)," J. Zool. Soc. Lond. 224, 223-232.

Thompson, P. M., McConnell, B. J., Tollit, D. J., Mackay, A., Hunter, C., and Racey, P. A. (1996). "Comparative distribution, movements and diet of harbour and grey seals from Moray Firth," J. Appl. Ecol. 33, 1572-1584.

Tremblay, Y., Shaffer, S. A., Fowler, S. L., Kuhn, C. E., McDonald, B. I., Weise, M. J., Bost, C. A., Weimerskirch, H., Crocker, D. E., Goebel, M. E., and Costa, D. P. (2006). "Interpolation of animal tracking data in a fluid environment.," J. Exp. Biol. 209, 128-140.

Tripovich, J. S., Hall-Aspland, S., Charrier, I., and Arnould, J. P. Y. (2012). "The behavioural response of Australian fur seals to motor boat noise," PLoS One 7(5), e37228.

Turner, J., Iliffe, J., Ziebart, M., Wilson, C., and Horsburgh, K. (2010). "Interpolation of tidal levels in the coastal zone for the creation of a hydrographic datum," J. Atmos. Oceanic Technol. 27(3), 605-613.

UNCTAD (2018). Review of Maritime Transport 2018 (United Nations, New York).

Urick, R. (1983). Principles of Underwater Sound (Peninsula Publishing, Los Altos, CA), 3rd ed.

Van der Graaf, A. J., Ainslie, M. A., André, M., Brensing, K., Dalen, J., Dekeling, R. P. A., Robinson, S., Tasker, M. L., Thomsen, F., and
Werner, S. (2012). "European marine strategy framework directive good environmental status (MSFD-GES): Report of the technical subgroup on underwater noise and other forms of energy," European Commission, Brussels, Belgium.

Van Parijs, S., Kovacs, K., and Lydersen, C. (2001). "Spatial and temporal distribution of vocalising male bearded seals-implications for male mating strategies," Behaviour 138(7), 905-922.

Veirs, S., Veirs, V., and Wood, J. (2015). "Ship noise in an urban estuary extends to frequencies used for echolocation by endangered killer whales," PeerJ PrePrints 4, e1657.

Ward, W. D., Cushing, E. M., and Burns, E. M. (1976). "Effective quiet and moderate TTS: Implications for noise exposure standards," J. Acoust. Soc. Am. 59(1), 160-165.

Williams, R., Bain, D. E., Ford, J. K., and Trites, A. W. (2002). "Behavioural responses of male killer whales to a leapfrogging vessel," J. Cetacean Res. Manage. 4(3), 305-310.

Williams, R., Erbe, C., Ashe, E., Beerman, A., and Smith, J. (2014). "Severity of killer whale behavioral responses to ship noise: A doseresponse study," Mar. Pollut. Bull. 79(1-2), 254-260.

Wittekind, D. K. (2014). "A simple model for the underwater noise source level of ships," J. Ship Prod. Des. 30(1), 1-8.

Wood, S. N. (2003). “Thin plate regression splines,” J. R. Stat. Soc. Ser. B 65(1), 95-114.

Wood, S. N. (2004). "Stable and efficient multiple smoothing parameter estimation for generalized additive models," J. Am. Stat. Assoc. 99(467), 673-686.

Wood, S. N. (2006). "Low-rank scale-invariant tensor product smooths for generalized additive mixed models," Biometrics 62(4), 1025-1036.

Zuur, A. F. (2009). Mixed Effects Models and Extensions in Ecology With R (Springer, New York) 